\title{
TEORÍA SOCIAL COMO «MÚSICA DE PALABRAS». ELEMENTOS DE ANÁLISIS (QUE NO SERÁN BIENVENIDOS) EN TORNO AL MARXISMO EDULCORADO DEL VENDEHÚMOS ACADEMICUS S. ŽIŽEK
}

\author{
SOCIAL THEORY AS A KIND OF 'WORDMUSIC'. \\ ELEMENTS OF ANALYSIS (NOT WELCOMED AT ALL!) ON SOME \\ SWEETENED MARXISM OF THE SCHOLAR-SMOKESELLER S. ŽIŽEK
}

\author{
Enrique Pedro Haba*
}

\section{RESUMEN}

Aquí se someten a escudriñamientos de orden analítico-realista los contenidos del difundido debate Peterson-Žižek, «Felicidad: Capitalismo vs. Marxismo». Queda así en evidencia el simplismo, la gran indeterminación (fórmulas vacías) y en general el escapismo de planteamientos (esencialismo, falacia intelectualista, etc.) como los ofrecidos por Žižek. Fue un pseudo-«debate»: no existe contradicción propiamente dicha, ni aun parcial, entre lo alegado respectivamente por esos académicos en sus exposiciones iniciales («vorbeireden»); $y$ menos que menos la hubo en cuanto a los enfoques de índole esencialmente parateologal hacia los cuales dirigieron su atención principal durante la segunda mitad de ese evento, sobre los que llegaron ambos a concordar hasta de manera expresa. Finalmente se añaden, al margen, unas observaciones sobre ciertas consideraciones de Žižek ulteriores: sus arengas (siempre en clave musica di paroli) de futurología esperanzada en el quehacer del covid-19 - muy bienvenido, pues debe abrir cauce a la definitiva ingeniería social salvífica globalista, gerenciada mediante imperium soberano de la alta burocracia internacional (ONU)—.

PALABRAS CLAVE: CAPITALISMO * IDEOLOGÍA POLÍTICA * MARXISMO * SOCIEDAD FUTURA * VIRUS

\section{ABSTRACT}

This paper offers an analytic-realistic scrutiny about the well known debate PetersonŽižek, "Hapiness: Capitalism vs. Marxism". Such examination makes it evident that Žižek's ways to approach (essentialism, intellectualist fallacy, etc.) suffer from oversimplification, great indeterminacy (empty formulae) and, in general, theoretical escapism. Anyhow, this was a pseudo-'debate': there were no fundamental contradictions, strictly speaking,

Facultad de Derecho, Universidad de Costa Rica, Costa Rica.

e.p.haba.m@gmail.com / enrique.haba@ucr.ac.cr 
between what was alleged by those two speakers in their initial expositions ("vorbeireden"); and both agreed even about the paratheological foundations towards which they directed their main attention on the second part of that event. Finally, some observations are added regarding certain further considerations by Žižek: his harangues about hopeful futurology (and as usual in the mood wordmusic), now based on the current work of covid-19 — very welcome for it should bring the salvific definitive globalist social engineering, managed through the sovereign imperium of UN officers.

KEYWORDS: CAPITALISM * FUTURE SOCIETY * MARXISM * POLITICAL IDEOLOGIES * VIRUS

\section{SUMARIO}

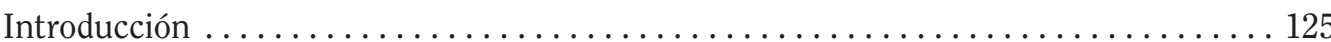

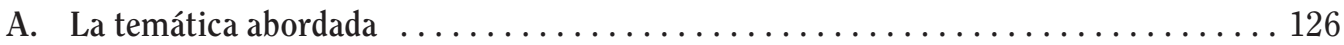

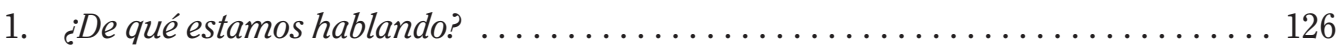

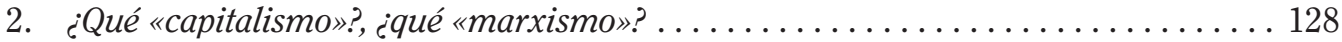

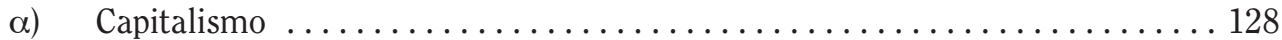

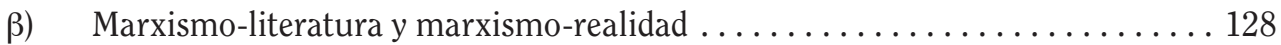

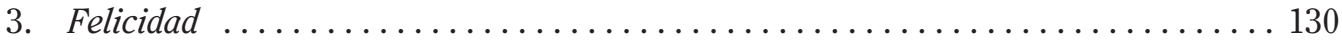

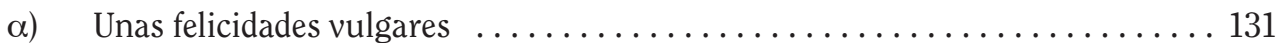

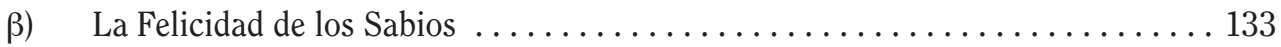

4. Especies de cuestiones consideradas . . . . . . . . . . . . . . . . . 137

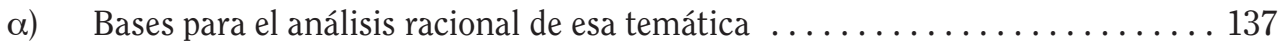

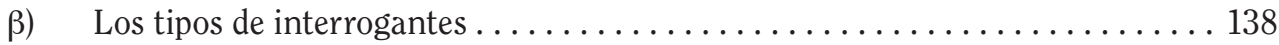

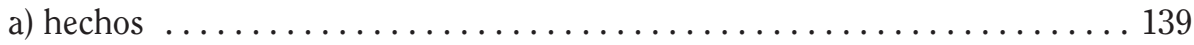

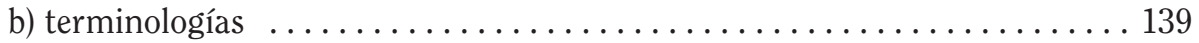

c) historia de unas ideas políticas . . . . . . . . . . . . . . . . . . . 139

d) practicidad social . . . . . . . . . . . . . . . . . . . . . . . 139

e) valoraciones . . . . . . . . . . . . . . . . . . . . . . . . . . . . . . . 139

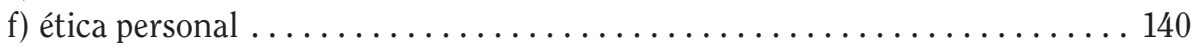

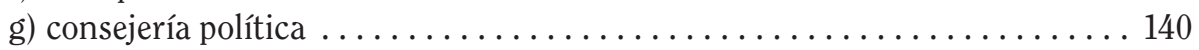

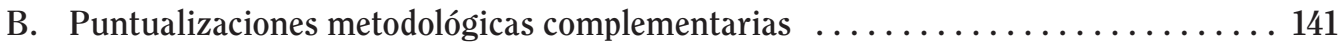

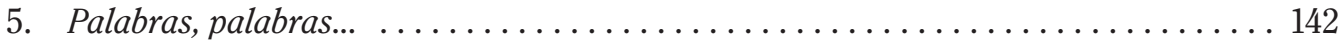

a) ¿Hay que activar El Significado Verdadero? . . . . . . . . . . . . . . . . . . . . . 142

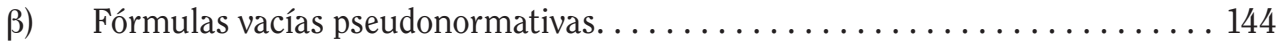

6. ¿Hacen falta pruebas? . . . . . . . . . . . . . . . . . . . . . . . 148

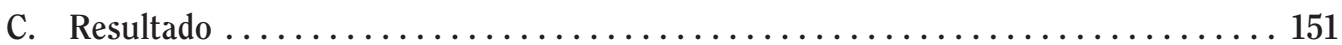

7. ¿De qué «conocimientos» se trata? . . . . . . . . . . . . . . . . . . . 151

8. ¿Hubo «debate»? ...................................... 154

9. Excurso: ¿Quién «ganó» este (pseudo)debate? ...................... 158

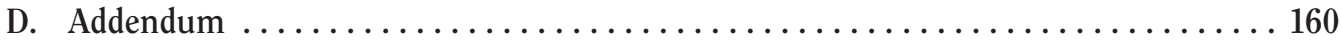

10. Maravillas sociales de última hora, avistadas (profetizadas) $\ldots \ldots \ldots \ldots \ldots \ldots$ gracias a la intervención salvífica del COVID-19 
... se le puede impresionar ofreciéndole, con aire grave, un desatino [o una trivialidad o una vaguedad de vaguedades] que suene como algo docto y profundo. Schopenhauer (2005, Estratagema 36, p. 36 y s.)

Deja que me regocije con un festín como el que las personas de espíritu ocioso suelen ofrecerse cuando pasean a solas. Esa clase de personas descuida averiguar por qué medios lograrían su deseo. Platón (1963, \# 458a, p. 296)

Los necios admiran todo en un autor de reputación. Voltaire (2019)

Tonel vacío resuena siempre mejor que tonel lleno. Villiers de l'Isle Adam (como se citó en Bouveresse, 2001, p. 37) $)^{1}$

El 19 de abril de 2019 tuvo lugar un evento que protagonizaron los celebrados youtubers Jordan Peterson y Slavoj Žižek, actividad programada para debatir sobre el tema Felicidad: Marxismo vs. Capitalismo ${ }^{2}$. Me ocuparé principalmente de lo que en esa ocasión dijo Žižek.

Por cierto, no me mueve que acaso yo mismo pueda estimar merecedor de señalado interés filosófico, pero menos que menos para ofrecer conocimientos en ciencias sociales, cuanto Žižek expuso allí. Mas ante el hecho de que tal manera de abordar cuestiones políticas obtiene amplia recepción laudatoria (jse ha calificado eso como «Debate del Siglo»! $)^{3}$,

$1 \quad$ El nombre completo del autor de la última cita es: Jean-Marie Mathias Philippe Auguste, Conde de Villiers de l'Isle-Adam (1838-1889).

2

Peterson y Žižek, 19 de abril de 2019. —En las citas que a lo largo del presente comentario se efectúan de ese evento, todas ellas recogidas de dicho vídeo, para cada una será indicada [entre corchetes] la altura de tiempo aproximada donde el pasaje respectivo se encuentra ahí, de acuerdo con la indicación correspondiente que aparece colocada al pie allí mismo.

3 La tónica más general de los comentarios al respecto marchó en el sentido de no alimentar ninguna duda en considerar que eso significó un «Acontecimiento de alta cultura», singularmente recomendable «popularización del saber» sobre me parece que no viene de sobra, quiérase o no, tratar de dirigir la atención hacia puntualizaciones como las puestas sobre el tapete aquí, justamente porque estas van muy a contravía de modos de razonamiento como los cultivados por dicho ideólogo.

Tales modus de razonamientos suelen hacerse presente también, no poco a menudo, aun en variadas otras orientaciones de discursividades académicas sobre lo social, fungen como asiento intelectual para encomiar teorizaciones escapistas en la materia. De ahí que el presente intento de des-velar esos recursos retóricos puede tomarse, si se quiere, como un ejemplo más para alentar a examinar con base en pautas analítico-realistas lo ofrecido en no pocos ejercicios académicos de teoría política. Semejanes pautas no suelen conducir a resultados de conocimiento reconfortantes ni para unas ni para otras modalidades de falacia intelectualista cultivadas en numerosos estudios de las ciencias sociales.

Para concentrarme en dicho objetivo principal de desmitificación, el presente examen va dirigido señaladamente al renglón [b] de los señalados a continuación. [a] El centro de mi atención no será dicho «debate» in toto, como planteamiento de conjunto, aun si cupiera suponer que de veras se hubiera asistido allí a la elucidación de unas fundamentales contradicciones de ideas claves entre lo respectivamente afirmado por esos expositores con respecto a algún asunto neto central. [b] Voy a examinar sobre todo lo expuesto por Žižek; me parece que justamente eso constituye una buena oportunidad, por haber obtenido tanta difusión este evento, para poner sobre el tapete la capital falta de sustento cognoscitivo $y$ en general la orfandad de pensamiento racional en que esos tipos de enfoques académicos consisten. [c] No llegaré a ocuparme sino muy al pasar de aspectos señalados allí por Peterson; efectuaré apenas algunas escasas referencias a él, secundariamente, unas destinadas

los temas tocados ahí [así, p. ej., en «Reflexiones y comentarios sobre el debate Žižek vs. Peterson»: https://www.youtube.com/watch?v=59Iw19MjSKA, 22/4/19 (las curs. [abrev. de cursivas] son añadidas por mí, E.P.H.). —Véase infra: $\$ 9$. 
para ilustrar también así el propósito principal de mi examen $[b]^{4}$.

En la primera Sección [A] entro directamente a analizar los principales ingredientes temáticos sustantivos de la heteróclita composición-storytelling contada ahí por Žižek; procuraré des-velar su enorme indeterminación lingüística y en general la falta de sustento por cuanto hace a conocimientos socio-empíricos primarios acerca de los temas que integran ese relato académico. La segunda Sección [B] es un complemento de la anterior, se dirige a llamar la atención sobre unos conocimientos fundamentales de metodología realista de las ciencias sociales que serán aplicados en [A]: por un lado, ello pone de relieve dos tipos de ingredientes estructurales básicos de linguo-«encantamientos» -Único significado Verdadero + múltiples fórmulas vacías- en discursos sobre lo social, a lo cual acude una $y$ otra vez ese relato de Žižek; por otro lado, conduce a advertir cuándo y cómo se requieren pruebas empíricas para acreditar conocimientos sobre las conductas colectivas humanas. La Sección conclusiva $[\mathrm{C}]$ resalta por qué, al fin de cuentas, no hubo «debate» propiamente dicho en esa ocasión. Y añadiré la Sección [D], posterior a ese debate, para hacer ver cómo la misma especie de expedientes retóricos sirve a dicho autor para mistificar, igualmente, la consideración sobre las cuestiones sociales involucradas en la actual pandemia (¿o «plandemia»?) virológica mundial.

Desde luego resulta contraintuitivo (atento a los hábitos lingüísticos normales) someter a aproximaciones de tal naturaleza, unas de orden propiamente analitíco-realista, el examen de los discursos políticos, inclusive sus idealismos académicos más connotados. Tales filtros de conocimiento científico sobre las conductas sociales terre ä terre previenen de ser «hechizado» (Wittgenstein) —allí lo fue también el propio Peterson- por enfoques como, por ejemplo, esos de Žižek.

4 Si bien considero atinada la exposición inicial de Peterson, mi objetivo aquí es poner sobre la mesa los principales ejes retóricos en que se asentó la marea de storytelling en que consistió el resto de dicha actividad.
$* * *$

Las observaciones que presentaré se dirigen a lectores potenciales que hayan tomado conocimiento directo, por su propia cuenta, de cuanto en dicha ocasión dijeron los protagonistas. Prescindo, pues, de ofrecer aquí un resumen de estas exposiciones. Los fragmentos que se reproducirán, van a título simplemente de ejemplos típicos sobre cómo «razona» Žižek, son muestras extractadas para ilustrar con toda especificidad los puntos en examen. [Si el presente artículo cae ante los ojos de personas que no estén al tanto de lo expuesto en ese «Debate», muy lejos de mí el venir a recomendarles que se esfuercen por conocerlo. Ni veo para qué pueda entonces valer la pena que dilapiden su tiempo en detenerse a considerar comentarios al respecto, desde luego que tampoco cuanto aquí voy a señalar yo.]

\section{[A]}

\section{LA TEMÁTICA ABORDADA}

La felicidad nos espera en algún sitio a condición de que no vayamos a buscarla.

Voltaire (2019)

No conciben a los hombres tal cual son, sino como ellos [los teorizadores] quisieran que fuesen. Spinoza (1985, p. 550)

\section{1. ¿ACERCA DE QUÉ ESTAMOS HABLANDO? \\ (... pero, ¿no es esta una pregunta \\ «traída por los pelos»?)}

Por cierto que el título elegido para esa actividad es, dada la prácticamente infinita amplitud de cuestiones subsumibles bajo él, como para dar «mala espina» de antemano, vaya a saber qué suertes de tutti frutti temáticos lleguen a ser metidos indistintamente ahí. Sin embargo, procuremos comenzar tratando de hacer algo así como «pasar en limpio» de qué se supone hayan venido a hablarnos los protagonistas de este evento. El título en cuestión, que por supuesto necesita ser muy aforístico como tal, apunta (si no estoy muy equivocado) a lo siguiente, si lo explayamos para fijar de 
modo más explícito la cuestión específica principal por abordar allí:

indagar cuál de las dos opciones ofrecidas por la alternativa de hierro «capitalismo»/«marxismo», como tipos netamente opuestos de organización político-social, ocasiona la «felicidad» o la no«felicidad» de mucha gente (¿es la de ciertos sectores en especial?), en grados drásticamente mayores el uno que el otro, como solución aplicable para cualquier sociedad actual (¿o para unas sí y otras no?) ${ }^{5}$.

[Nota: ¿...y si la temática fue otra? Estoy suponiendo que el «debate» procuró, al menos centralmente, responder a lo señalado en su título. Mas podría ser que, como sucede no pocas veces, el título de una presentación no da cuenta bien sobre cuáles son de veras el o los objetos de referencia principales abordados allí. Y cuando el propio contenido de esas elucidaciones es atinado, aunque no se refiera especialmente o lo haga poco a lo señalado en el título, desde luego que la validez de esas reflexiones no deja de ser tal por esa caracterización inicial poco apropiada. No tengo óbice en reconocer que calibrar la pertinencia de este título es lo de menos, se podría haber elegido algún otro... ¡o ninguno! Por más que a uno le cueste (al menos es mi caso) discernir algo así como un «hilo» central en ese popurrí de pincelazos exclamativos enunciados por Žižek en dicha ocasión, podría ser que cada uno de

5 Significa que, explicitado en forma más laboriosa, se trataría de conocer si, para obtener felicidad (sea íntegra o en el mayor grado posible humanamente) para la generalidad (o, en todo caso, la inmensa mayoría) de las personas de determinado país o de varios (¿o tendría que ser en todos a la vez?), es indispensable (segura o muy probablemente) que: a) ahí la organización social esté fijada ya sea siguiendo al pie de la letra (¿o en cuáles aspectos principales?) el modelo-«marxismo» o bien el modelo-«capitalismo»; b) y correspondientemente ver si también es inexorable que, en cambio, la puesta en práctica de ya sea el primero o el segundo de dichos modelos determine, por sí mismo, respectivamente la $n o-« f e l i c i d a d »$ de las personas sujetas a tal organización. estos sea rescatable por sí mismo, como en un cuaderno de apotegmas. ¿No será que allí, con independencia del título, esos señalamientos hayan abordado interesantemente otras cuestiones, unas que de todas maneras revisten interés propio como conocimientos sobre muy importantes aspectos de lo societal? Considero que las puntualizaciones al respecto que señalaré a lo largo del presente comentario mantienen toda su atingencia para los asuntos de fondo tocados en esa ocasión, sea o no sea que estos mismos se correspondan bastante con lo señalado por el título elegido.]

$$
* * *
$$

Cualesquiera sean las respuestas sustantivas que se ofrezcan sobre la temática propuesta, no se ve cómo puedan ser obtenidas sin partir, al menos implícitamente, de ciertas ideas - sean las que fueren - en cuanto a qué quieren decir ahí las tres palabras centrales que componen el susodicho título. Ahora bien, ¿es obvio qué significa cada una de ellas? ¿Su respectiva comprensión es claramente consabida -intensión (semántica) y extensión (pragmática) - por la generalidad de los hablantes (intersubjetividad) del idioma español, o en cierto sector amplio de ellos, casi siempre o en todo caso por cuanto hace a los contextos para los cuales fueron utilizados estos términos como núcleos de referencia en esta ocasión? ¿Quedan distinguidas de veras (i.e., intersubjetivamente) las conductas humanas encomiadas por Žižek, frente a cualesquiera otras, siempre o casi siempre o al menos para la amplia mayoría de las situaciones a que esos términos son aplicables por hablantes que tengan costumbre de usarlos?

Supongamos, aunque no es poco conceder, que puede haber unas cuantas personas, ya sean algunas pocas (líderes o jefes de Estado o cuerpos legislativos) o muchas (llamémoslo «pueblo»), preocupadas por tratar de realizar escrupulosamente las indicaciones de Žižek. Pues bien, para descubrir QUÉ necesitarían hacer estos benefactores de la humanidad, con vistas a cumplir ni más ni menos que con esas especies de acciones, no es dable proceder a ello sin tener claro lo siguiente: 
- i) ¿«felicidad» según la opinión de quiénes?

- ii) ¿«marxismo» según es entendido por quién y en cuanto a qué cuestiones específicas?

iii) ¿cuáles aspectos de lo llamado «capitalismo»?

En modo alguno me mueve el propósito de diferenciar matices lingüísticos por un propósito de orden esencialmente semánticodiccionaril. Al contrario, por mi parte considero que debiera aplicarse con severidad «la navaja de Occam» en las teorías de la ética y de la política; muy a diferencia, ciertamente, de dirigir esas teorías a desplegar vueltas y revueltas a propósito de unos u otros embelesos discursivos de politología celestialista. Mas con respecto a planteamientos como los que serán examinados aquí, no resulta posible aplicar saludablemente tal «navaja» si no se empieza por tomar conciencia de cuáles son los variados sentidos que se confunden entre sí cuando los términos en cuestión aparecen utilizados sin unas precauciones analíticas elementales.

\section{2. ¿QUÉ «CAPITALISMO»?, ¿QUÉ «MARXISMO»?}

\section{a) CAPITALISMO}

Este término es susceptible de ser definido con más o con menos detalles; cualquier investigación con respecto a lo así mentado puede concentrar su atención principalmente ya sea en unos u otros aspectos de ello. Como Žižek no considera del caso señalar definición alguna al respecto, ni explicita ni implícita, cabe suponer que dicha palabra la toma de acuerdo simplemente con algo así como la definición canónica generalísima que ofrece la Real Academia Española: «Sistema económico basado en la propiedad privada de los medios de producción y en la libertad de mercado».

Esta definición no diferencia grados para ese «basado en», señaladamente es de notar que no lo hace por cuanto respecta a «libertad de mercado». Aun en los países donde el Estado la restringe en grados menos elevados que en otros, queda sometida a múltiples restricciones: monopolios estatales en ciertas actividades $y$ privilegios concedidos a algunas empresas en particular (sus mercados «cautivos» porque el Estado impone que solo pueden ser atendidos por unas empresas privadas prebendarias de tal beneficio otorgado por él: «empresaurios» se les ha llamado en Argentina), prohibiciones, impuestos, múltiples reglamentaciones de funcionamiento y tramitología.

Al hablar de «capitalismo» como lo hace Žižek, no se contempla diferencias sensibles al respecto entre cómo eso tenga lugar entre distintos países: ¿tanto da, para aquello sobre lo cual entiende dictaminar él, «capitalismo»hoy en EE.UU. o en Argentina o en Haití, por ejemplo? No hay por qué, claro está, adjudicarle a Žižek ignorancia en cuanto a las grandes disimilitudes entre cómo vive la gran mayoría de la gente en esos países respectivamente; sin embargo, de la manera como las cuestiones sociales son planteadas por él, no se ve que tales diferencias las considere determinantes con vistas al quid -llámele «felicidad», «libertad», «dignidad», «autenticidad», «verdad», o como fuere ${ }^{6}$ - en las conductas humanas que a él le interesan sobre toda otra cosa.

Es cuestión de preguntarnos si, aun siendo presentado ahí de manera tan indiscriminadamente holista el ítem «capitalismo» de la comparación propuesta, así y todo pueda esta hacer advertir unas percepciones de singular interés sobre fenómenos sociales. Pero antes examinemos si es mucho menos indeterminado, acaso, lo que se trajo a colación allí en cuanto a «marxismo» $y$ «felicidad».

\section{B) MARXISMO-LITERATURA Y MARXISMO- REALIDAD}

El término «marxismo» designa dos universos de referentes: un sector de literatura y un sector de organizaciones estatales reales, ambos subsumibles bajo esa misma palabra. Pero he aquí que estas dos esferas resultan ser no poco independientes entre sí; bien puede decirse que se trata, respectivamente, de algo así

6 Son expresiones empleadas por Žižek [véase infra: en el grupo de citas reunidas un poco más adelante de donde se indica la n. 26]. 
como los marxism in books [a] y los marxism in action $[\mathrm{b}]^{7}$.

Salta a la vista que no es más o menos lo mismo: [a] preguntar qué dicen o no dicen unos textos afamados del «marxismo»-literatura - examinar cómo debieran ser entendidos o qué sea dable inferir de ellos en sí mismos-; [b] indagar qué sucede efectivamente en los Estados cuyos gobernantes se autopresentan como marxistas — «marxismo»-realidad-.

Es verdad que la realización de lo segundo no es ajena a unas influencias provenientes del conocimiento, en algunos protagonistas suyos muy decisivos, acerca de tales o cuales señalamientos que forman parte de lo primero. Por supuesto, también cabe examinar qué influencias comprobables hayan tenido o puedan llegar tener ciertas partes de [a] para determinar implementaciones fundamentales de [b], o aquilatar valorativamente cómo se parece o cuánto difiere lo programado en [a] de lo realizado en [b]; pero aun tales investigaciones requieren distinguir entre lo propio respectivamente de ambos planos. Sin perjuicio de reconocer que existen esos tipos de relaciones, lo cierto es que las modalidades y grados en que puedan darse realmente sus concreciones son de lo más variados y contingentes. En una palabra: la lectura de [a] no equivale a conocer [b)], caben toda suerte de desfases y de contradicciones entre lo uno $y$ lo otro.

Aun si nos limitamos a considerar el marxismo-literatura, cualquier cosa señalada como contenidos suyos presupone haber determinado, así sea tácitamente, a cuáles autores (o ciertos grupos restringidos de ellos) se entiende hacer referencia, entre la infinidad de quienes han escrito textos que se proclaman como inscritos dentro de esa gran corriente doctrinaria. A nadie se le ocurrirá suponer que cuanto diga él mismo armoniza sin más con todo lo sostenido por el conjunto de esos autores, ni aun con la totalidad de lo escrito por alguno de ellos en

7 Recojo, mutatis mutandis, la clásica distinción entre law in books y law in action (R. Pound, K. N. Llewellyn) sobre la cual se llama la atención en estudios del realismo jurídico [cfr. Haba, 2012, Sec. D.III.6 («Paper rules»)]. especial. Quienes se identifican como «marxistas» entienden basarse señaladamente en los escritos de Marx y Engels; pero puede ser que se apoyan también en opiniones de unos u otros marxistas de renombre (por ejemplo: Kautsky, Luxemburgo, Lenin, Trotski, Stalin, Mao, Gramsci, Althusser).

En dicha ocasión, no dejó lugar a dudas $q u e ́$ entendió señalar Peterson mediante el término «marxismo», son determinadas puntualizaciones contenidas en el Manifiesto Comunista. Žižek le reprochó justamente eso: entendió que alcanza con subrayar que tal delimitación temática es de lo más «estrecha», pues ciertamente Marx dejó dichas buena cantidad de otras cosas (books!).

Ahora bien, es cierto que la definición estipulativa de «marxismo» se puede circunscribir de muchas maneras diferentes, según de qué elijan ocuparse los interlocutores, basadas en unos $\mathrm{u}$ otros pasajes escogidos en el seno de los cientos de páginas escritas por Marx; es aceptable, naturalmente, que Žižek haya preferido seleccionar de ahí ideas a las que no se refirió Peterson. No queda claro, empero, cuáles sean los pasajes o estudios pertenecientes a Marx que según Žižek se debieran escoger para examinar lo encarado en ese debate... iy cuáles no! Salvo que se tome ahí como determinación conceptual de «marxismo» considerar los contenidos de la totalidad de las obras de este autor, en cuyo caso resulta prácticamente imposible responder a la pregunta central establecida para ese debate: no se echa de ver cómo sería dable examinar lo de la «felicidad», sea esto mismo lo que fuere, en relación con todos y cada uno de los pensamientos escritos por Marx.

Tampoco queda claro cuál sea la relación entre «marxismo» $y$ «comunismo», de la manera como estos términos los empleó Žižek. Acaso «marxismo» sería la teoría, mientras «comunismo» sería la práctica histórica de los regímenes denominados asî́; mas al parecer él

$8 \quad$ Palabras de Žižek «...fracaso del proyecto comunista del siglo Xx...» [1:02:45]. 
llama «comunismo» también a unos ideales en la materia ${ }^{9}$.

Podría aducirse que, si bien Žižek no toma el cuidado de señalar de modo expreso a qué le llama «marxismo» (salvo en cuanto por vía de inferencia negativa queda aclarado que, para aquel, ello no debe ser lo definido como tal por Peterson), acaso se podría entender que él determina eso en forma tácita. Esto es: «marxismo» serían, por contraposición a cuanto corresponde llamar "capitalismo» [digamos que esto otro esté bastante claro ${ }^{10}$ ], todas aquellas medidas de organización social y actitudes personales que el propio Žižek encomia en su exposición ${ }^{11}$. Visto de esta manera, al fin de cuentas tanto da si esos buenos consejos los haya presentado Marx mismo o sea dable inferirlos (con certeza o supuestamente) de unos textos de este autor, o si proceden también (sea complementaria o sustitutivamente) de alguna otra fuente doctrinaria o acaso se le ocurrieron «solito» a Žižek ${ }^{12}$.

Lo más interesante no es, después de todo, dictaminar acerca de si es correcto (exégesis literaria) denominar propiamente «marxismo» a las recomendaciones de Žižek; tanto más cuanto que él recurrió bastante poco a esta palabra allí, y hasta lo hace salvando ciertos reparos teoréticos al respecto ${ }^{13}$. De lo que debiera tratarse sobre todo, a mi juicio, es fijarse en qué pertinencia tengan tales observaciones por sí mismas, sean cuales fueren los membretes de doctrina bajo los cuales se las presente subsumidas. Y sobre todo, si el asunto es pensar como alternativa que las sociedades se organicen según cierto modelo ideal llamado

$9 \quad$ Palabras de Žižek: «... sé que es provocativo llamar a esto una defensa del comunismo...» [1:09:40].

10 Supra: punto $\alpha$ ).

11 Infra, cfr. las citas correspondientes a: nn. 17 a 21 $+\S 3$ in fine $+\S 4 . \beta \cdot g_{2}$.

12 Si uno se interesa por conocer estudios verdaderamente penetrantes sobre la gran variedad de ideas que componen la corriente llamada «marxismo», altamente recomendables son: Fetscher, 1971; Gouldner, 1983; Kolakowski, 1980.

13 Palabras de Žižek: «...estúpida antropología marxista» [1:35:00]; «...el peligro está en la estructura teleológica del marxismo» [1:40:00]. «marxismo» - books!-, la cuestión decisiva es: saber cómo eso, sea lo que fuere, llegaría a encontrar QUIÉNES (dirigencia política y demás) lo establezcan realmente y enterarse de qué MANERAS ello funcionaría en la práctica (economía $y$ demás $\left.{ }^{14}\right)$-action!-.

Al fin de cuentas lo cierto es que, y sea como fuere por cuanto hace a la definición de «marxismo», he aquí que ese «marxismo» pregonado por Žižek no es mucho más que un salpicado de «fórmulas vacías» [infra $§ 5 . \beta)$ ].

\section{FELICIDAD}

Veamos qué es dable sacar en limpio sobre el propio objetivo temático central propuesto ahí: cómo alcanzar «felicidad» humana y cuáles son unos obstáculos sociales fundamentales que impiden lograrlo. $¿$ «Felicidad» consistente en qué, para quiénes como sus portadores reales, obtenible por cuáles medios? ${ }^{15}$.

El término «felicidad» es comprendido principalmente: a) ya sea entendiendo por ello la obtención y conservación de las especies de «cosas» (subjetivo-personales y objetualexternas) a qué aspiran la inmensa mayoría de las personas de un medio social o las de cierto tipo histórico-cultural de colectividades, según como lo piensan esos individuos mismos; b) ya sea como realización de tales o cuales ideales de sentimientos y comportamientos, de acuerdo

14 A título de ilustración: compárese el enfoque a lo Žižek con observaciones «terrenales» tan básicas como las puntualizadas en la sintética presentación que es ofrecida sobre la problemática en cuestión en Kaiser y Brennan, 26 de julio de 2019.

Las elementalísimas puntualizaciones al respecto que ofreceré a continuación no apuntan más allá, como señalo arriba, que intentar pasar «en limpio» apenas muy básicamente a qué pueda tal vez referirse ese asunto aun en una exposición como esta de Žižek. Desde luego, quien desee considerar observaciones verdaderamente penetrantes sobre tal cuestión tendrá que dirigirse a muy otras fuentes de conocimiento que señalamientos como los de dicho autor [p. ej.: véase las observaciones «vitales» reunidas en el conocido librito de Russell, 1971; o bien, directamente centrado en cuestiones de teoría política, las agudas puntualizaciones presentadas en nuestros días por Kaiser, 6 de noviembre de 2018]. 
con lo encomiado en unas u otras literaturas filosóficas, religiosas, éticas, de consejería psicológica y demás.

Si bien puede ser que ambos rubros [a) $y$ b)] coincidan en ciertos aspectos, para circunstancias en que se ven envueltas tales o cuales personas (muchas o pocas), este acoplamiento no puede darse por descontado de antemano. Saber si semejantes coincidencias existen, $y$ en qué medidas, es cuestión para ser examinada mediante verificaciones empíricas, variables en el tiempo y en el espacio. De todas maneras, no es lo mismo investigar (a) que dar cuenta sobre postulaciones consignadas en (b), cualesquiera fueren las eventuales relaciones (hipotéticas o reales) entre ambas cuestiones. Llamémosles, respectivamente: $\alpha$ ) «felicidad» vulgar, $\beta$ ) «felicidad» de los Sabios.

\section{a) \\ UNAS FELICIDADES VULGARES \\ (¿qué «cosas» anhela la gente?)}

This book is not adressed to highbrows, or to those who regard practical problem merely as something to be talked about. Russell (1971, p. 10)

Si el asunto es identificar los contenidos sustantivos de conciencia que llamamos «felicidad», tal como se nos hacen presentes subjetivamente, ya sea porque sentimos que los poseemos o porque sabemos a qué aspiramos para alcanzarla, eso no es difícil de reconocer por parte de cada quien con respecto a sí mismo. Ante la pregunta si somos felices o qué nos haga falta para serlo (esto último es lo más habitual), contestamos señalando tales o cuales «cosas»-aspectos físicos personales, objetos materiales, conductas de otros individuos, etc.- que deseamos tener a nuestra disposición, las cuales revisten distintos grados de importancia en nuestras escalas de preferencias.

Entre esas «cosas» puede haber unas que nos resultan inalcanzables, de lo cual hasta podemos darnos plena cuenta (p. ej., volver a estar en ciertas condiciones del pasado), o que haya probabilidades distintas de alcanzarlo y requerir ciertas conductas nuestras para esos efectos; sea o no sea que tengamos conciencia realista al respecto (p. ej.: sabemos que depende del azar ganar la lotería, pero tal vez no sepamos qué pueda favorecernos para emprender determinados buenos negocios). Ello depende de los grados de desfase existentes entre las «cosas» a que aspiramos (según sean «vistas» por uno mismo) y lo que poseemos ahora (i.e., «poseído» en cuanto lo reconocemos como nuestro ya). Cuanto menores sean tales desfases, ante nuestros propios ojos, en esa «medida» nos sentimos relativamente «felices» en el momento considerado; y a la inversa, tanto más desdichados nos sentimos cuanto más intenso sea el grado en que a los desfases considerados los experimentemos como sensaciones de «vacío» (p. ej., carecer de ciertos objetos o la ausencia de una persona) o de «carga» (p. ej., ciertos dolores físicos o condiciones de trabajo agobiantes).

Salta a la vista que esas maneras de felicidad son infinitamente variadas. No solo se sienten de maneras distintas de individuo a individuo, en rigor no hay dos seres humanos cuyas conciencias sean iguales; inclusive se transforman estas a lo largo de la existencia de cada persona. Es verdad que hay numerosas situaciones típicas de la vida humana concernientes a ello, y más específicamente aún si nos referimos a un medio social determinado; también es cierto que hay bienes anhelados por la generalidad de las personas, repartidos de maneras desiguales entre estas. Sin embargo, la «medida» de la falta o la presencia de tales o cuales bienes en la vida de cada quien es experimentada de las maneras más variadas si comparamos cómo «se lo toman» unos y otros individuos; p. ej., bien puede ser que alguien con toda abundancia de recursos económicos se sienta mucho más in-feliz que un obrero de sueldo bajo, o que entre funcionarios públicos que ganan lo mismo haya unos que se sienten desdichados $y$ otros moderadamente satisfechos con su vida. No hay, a decir verdad, unas medidas comunes en autopercepción de «felicidad»; si bien es cierto que, en cambio, hay tipos característicos de situaciones extremas que normalmente se sienten como no-«felicidad» (enfermedades, hambruna, fallecimiento de seres queridos, etc.).

Seguramente ciertas disposiciones tomadas por una organización estatal repercuten 
en que tales o cuales sectores de personas se sientan más felices o más desdichadas, en grados mayores o menores, para ciertos aspectos de sus vidas, en un tiempo dado. Es obvio, por ejemplo, que las disposiciones específicas del «Socialismo del siglo xxI» mediante las cuales el régimen chavista fue llevando a Venezuela a su situación actual no han hecho felices a los millones de venezolanos emigrantes, ni a la enorme mayoría de la población que actualmente allí pasan hambre y falta de servicios básicos (medicinas, agua, electricidad); en cambio, por los opíparos beneficios personales que ese régimen pone en manos de sus principales jerarcas (gobernantes $y$ altos mandos militares) y de los particulares beneficiarios («boliburgueses») en superlucrativos negociados llevados a cabo en connivencia con aquellos, estos grupos especiales tienen a su disposición ciertos modos de «felicidades» no poco excepcionales. Paralelamente, en la crisis económica mundial de 2008, los gobiernos capitalistas corrieron a amparar la «felicidad» de los banqueros proporcionándoles multimillonarias inyecciones de dólares tomados de las arcas estatales; a diferencia, eso sí, de la no«felicidad» que esa crisis produjo en numerosos deudores hipotecarios y al ocasionar altas cifras de desempleados.

Por supuesto que las políticas estatales, ya sean normales o unas excepcionales, cuentan entre los múltiples factores que pueden tener efectos decisivos sobre las vidas de las personas (incluso hay países donde unos organismos oficiales se ocupan específicamente de la «felicidad» de sus ciudadanos: p. ej., en Venezuela ${ }^{16}$ ). Mas lo cierto es que, salvo por

16 «Nace el viceministerio para la Suprema Felicidad Social del Pueblo Venezolano. El presidente Maduro crea una nueva instancia para supervisar los programas sociales ideados en colaboración con La Habana» (El País, 25-10-2013 (https:// elpais.com/internacional/2013/10/25/actualidad/1382671557_894752.html). «La ministra de la Felicidad de Emiratos Árabes Unidos (EAU), Ohoud al-Roumi, juró su cargo junto a los demás ministros que componen el nuevo gabinete del país del Golfo Pérsico» (HispanTV, 16/02/2012, https://www. hispantv.com/noticias/oriente-medio/215207/ministra-felicidad-jura-cargo-emiratos-arabes-unidos). cuanto hace a reducir ciertos factores de no«felicidad» extremos (brindar servicios médicos para sectores sociales de ingresos muy bajos, encargarse eficientemente de la seguridad pública, etc.), la multifacética gama de las posibles felicidades/infelicidades reales no es susceptible de ser prevista $y$ determinada mediante ninguna organización humana (... y, a estar por todas las evidencias, ni aun por la Voluntad de Dios). Acerca de eso no veo qué puedan aclarar planteamientos como los de Žižek, esto es: en cuanto a ofrecer conocimientos nuevos acerca de las aspiraciones reales habituales $y$ experiencias reales comunes de «felicidades», en colectividades dadas efectivamente, ni para unas organizaciones socioeconómicamente probables (sean cuales fueren) en futuros previsibles.

Anotaciones como las de ese autor no conducen la atención, antes bien la difuminan, hacia advertir elementos sustanciales que de por sí no se encuentren bastante divulgados ya (aun sin necesidad de conocer ni un ápice sobre Historia de la Filosofía). En efecto, brilló por su ausencia en los señalamientos suyos allí:

- [a] Des-cubrir la intervención de determinadas circunstancias empíricas que sean poco conocidas, entre las que comprobadamente obstaculizan o promueven la «felicidad», en tales o cuales aspectos específicos comunes para personas corrientes de un medio social determinado o de varios similares. Tampoco se ofrecen pistas en cuanto a dónde o por qué vías sea dable indagar aquellas.

[b] Describir unos inéditos, o al menos muy poco difundidos, planeamientos colectivos específicos; o algunas medidas particulares concretas para determinados asuntos sociales en especial. Esto es: novedosas soluciones viables (no digo seguras, pero en todo caso no imposibles o muy altamente improbables), aptas para cambiar tales o cuales prácticas sociales cotidianas bien determinadas; atento a las dinámicas socioeconómicas reales presentes o mediante cambios empíricamente probables al respecto, para tales o cuales coordenadas de espacio actuales 
(¿o para todas ellas?). Cuanto sea preguntarse sobre cómo funcionan, o es bastante probable que pudieran funcionar, las ordenaciones económicas efectivas en unas organizaciones sociales, para facilitar «felicidad» o sea lo que fuere en la gente: estas son interrogaciones de las cuales en universos mentales como los accedidos por Žižek no hay inconveniente en hacer abstracción sin más.

De todas maneras, no es para nada ajeno a la evidencia empírica el hecho psicológico de que, sean cuales fueren los bienes «mundanos» anhelados por cada quien, resulta que, aun en caso de alcanzar a obtener los que uno considera principales en cierto momento de su vida, la sensación de «felicidad» que ello le proporciona no suele ser duradera en su plenitud; no mucho después, la idea de «dicha» pasa a fijarse en obtener otras «cosas». La «felicidad» viene a ser, al fin de cuentas, antes bien algo así como correr en pos de un espejismo.

$$
* * *
$$

Lo que al respecto nos propone la literatura más prestigiosa (religiosa, filosófica, etc.) es bastante diferente de los objetivos - fuera de los más elementales: salud, alimentación, etc.- que mueven a la inmensa mayoría de las personas. Señaladamente, cuando el asunto es volar por «regiones» (Wittgenstein) discursivas como aquellas hacia las cuales dirige su atención Žižek no hay por qué distraer la atención hacia [a] y [b]. De ahí que advertir sobre la ausencia de información como esa requerida para estos rubros puede ser visto como un reclamo que está completamente fuera de lugar por cuanto hace a lo abordado en ese «debate». En cambio, ahí fue muy bienvenido concentrar la atención sobre otro tipo de «felicidad». Me detengo en ello a continuación.

\section{LA FELICIDAD DE LOS SABIOS}

Los hombres siempre estarán locos y los que piensan que pueden curarlos son los más locos de todos. Voltaire (2019)
El «sentido» propio de elucidaciones del tipo propuesto por Žižek no consiste, claro está, en procurar ofrecer un «frío» estudio descriptivo sujeto a rigores metodológicos de las ciencias sociales; se dirige sobre todo a plantear un desglose de ideales humanos supremos y de «fundamentos» filosóficos supra-empíricos al respecto. No es cuestión, pues, de venir a perder de vista que justamente es este el nivel de «profundidad» en reflexiones requerido para poder acceder a tal orden de saberes. De ahí que bien puede entenderse (de esto se hallan convencidos, probablemente, la abrumadora mayoría de los enseñantes de la materia oficial Filosofía en centros de enseñanza estatales) que detenerse en asuntos como los susodichos [a]-[b] sería sucumbir a unos modos de pensamiento «reduccionistas» sobre las cuestiones principales de la conducta humana. Dirán que lo elucidado por Žižek atiende a otra «cosa».

El moderador logró percibir que, en efecto, para los dos expositores no se trató de cómo alcanzar los fútiles modos de «felicidad» por los cuales se preocupa el vulgo [supra $\alpha$ )]:

«Ambos ... habéis sido muy críticos con la felicidad como mero hedonismo, búsqueda de placer o simplemente como un sentimiento. ¿En qué consiste la verdadera o profunda felicidad humana y cómo se consigue?» [1:56:30].

En efecto, la «felicidad» que le importa a Žižek no pertenece al orden de las empíricovulgares, esas que desvelan a los no-filósofos. Estas últimas se componen simplemente de aspirar a tener cosas como: «... os garantizamos una vida relativamente segura: empleo, placeres privados, privacidad, etc.» [1:28:00]. Lo que ocupa la atención de Žižek no son cuestiones prosaicas: «...mi argumento aquí es problematizar la felicidad» [1:25:00]. Aquella aspiración vulgar de las gentes constituye, para él, «la naturaleza corruptiva de la felicidad» [ibid.]. De lo que debe tratarse por encima de todo es:

«... encontrar una causa significante más allá de la lucha por una supervivencia placentera» (...) hacer nuestro deber (...) [dar] prueba de autenticidad 
(...) [abstenerse de] la envidia, el resentimiento (...) enfocar mi vida en problemas creativos...» ${ }^{17}$.

¿Qué tiene todo esto que ver con «felicidad»? Žižek subraya que al respecto: «mi dogma básico es "la felicidad debería ser tratada como un subproducto necesario"» [1:28:50]. De ahí que:

«... veo seguridad social y educación y demás, como algo que me permite a mí enfocar mi vida en problemas creativos más importantes. Veo a esta básica igualdad de oportunidades [como] un espacio para crear diferencias, y por qué no, jerarquías diferentes, más apropiadas» [55:30]. «... la felicidad es un aspecto colateral. No es una cosa en sí misma. Es algo que viene sobre ti, es como un acto de gracia $^{18}$ en cierto sentido» [1:57:00], es como «caer en el amor ("fall in love")» $\left([2: 02: 00]^{19} ;\right.$ «... si te enfocas en ella [la felicidad] estás perdido». La felicidad auténtica no existe sino en tanto en cuanto esta «Aparece como un subproducto de ti trabajando para una causa, etc.» [1:29:00]. «Para mí la felicidad no consiste en alguna unidad dichosa de valores supremos. Es la lucha misma, la caída ${ }^{20}$ y demás» [2:04:50]. Y señala Peterson, por su parte: «El medio más eficaz para perseguir la buena vida,

Citas más completas: infra, inmediatamente después del párrafo que sigue a indicar la n. 26 [allí las referencias exactas]. - Nota: tanto en esta como en las demás transcripciones de ese evento que efectuaré a lo largo del presente texto, los énfasis (mediante cursivas o negritas) se añaden por mi propia cuenta (E.P.H.).

«...la categoría de gracia puede ser usada perfectamente en un sentido ateo, es una de las categorías más profundas» [1:55:00].

Véase también infra: n. 21.

Žižek se refiere así a algunas divagaciones suyas de orden teologal (¿o parateologal?), donde al episodio bíblico de la crucifixión de Cristo le imputa aquel ciertos misticismos aparte pergeñados de acuerdo con sus propios gustos hermenéuticos, unos de corte señaladamente hegeliano [2:03:40]. que no es lo mismo que perseguir la felicidad, es adoptar algo parecido a una postura de máxima responsabilidad ante el sufrimiento y la maldad en el mundo. (...) conceptualizar el bien supremo que tú puedas conceptualizar, eso es lo primero» $[1: 50: 00]^{21}$.

No es difícil reconocer ahí la visión escatológica de reorganizar la sociedad para que entonces florezcan los desempeños del hombre «nuevo». Ideal subrayado por Marx en sus escritos más juveniles, después por Marcuse $y$ otros. Pues bien, me aventuro a creer que inclusive para realizar tales anhelos — «causa significante», «buena vida» y demás - no vendría de sobra saber cómo resolver unas cuestiones prácticas que guardan no poca cercanía con los extrapoéticos asuntos [a] y [b] —supra: punto $\boldsymbol{\alpha})$ - Sin embargo, cabe reconocer que quien efectúa una exposición académica puede hacer uso de su buen derecho de no hablar sobre cuestiones que prefiera dejar afuera de sus propios «recortes» objetuales de examen ${ }^{22}$. De ahí que los elementos de juicio realistas [supra:

21 Acotación. - A esa altura, Peterson se ha lanzado de pleno gusto en los brazos de las «tónicas» discursivas - ultravaguedades, emotivización + definiciones persuasivas, entremezclar indiscriminadamente lo que son alternativas en cuanto a facticidades psicológicas y unos juicios de valor categóricos, en general confusión entre puntualizaciones científicas de psicología social y consejería moral, etc. - a que recurre el propio Žižek. En efecto, la «felicidad» a que se refiere Peterson es algo que, según Žižek: «... tal vez si eres sabio consideras esto como un milagro menor incomprensible, que de alguna manera te encuentras en el lugar adecuado en el momento adecuado...», cuestión de "gracia», etc. [1:58:00]; la «verdadera felicidad desciende sobre ti», «es algo que es auténtico y que existe dentro de nosotros y constituye una guía adecuada...» [2:01:20]. Žižek no deja de destacar su entusiasta acuerdo con tal manera de abordar las cuestiones, inotablemente en atención a que así la problemática atendida pasa a ser encarada ni más ni menos que como unos asuntos de «gracia»! [1:57:20].

22 Cfr. Haba, 2019: § 6b (p. 32 y ss., «De qué, y cómo, puede apartar la vista determinada teoría: su "recorte" objetual»). 
punto $\boldsymbol{\alpha}$ )] no tienen por qué desvelar a «pensadores» como Žižek.

Si bien se mira, ciertamente puntualizaciones como estas mías vienen a errar «el «blanco» por cuanto hace a descubrir cómo debe $y$ puede quedar configurada la Felicidaddel-Sabio o la Vida-Buena, en la Tierra-de-lasMil-Maravillas. Quien guste ubicarse en tales planos de elucidaciones puede también, ipor qué no!, utilizar la palabra «felicidad» para etiquetar sus preferencias al respecto; sea o no que aun esto mismo se catalogue como «subproducto» de orden «colateral», cuya «autenticidad» consistiría en «trabajar por una causa» o para «el bien supremo»... Ilimitadas como son las capacidades de fabulación en la especie humana, $y$ para vestir tales creaturas del pensamiento mediante verbalizaciones $a$ piacere («universos simbólicos» cotidianos ${ }^{23}$, ciertas terminologías filosóficas, etc.), he aquí que la palabra «felicidad» no solo presenta sus usos normales, aquello indicado más atrás $[\alpha)$ ]. Vemos que puede ser presentada también de otras maneras, en ciertos órdenes de discursos profesorales.

En unas exposiciones de ese orden, esta palabra pasa entonces a significar, ya no datos que se aprehenden/disciernen empíricamente (características de fenómenos psicológicos individuales y ciertas específicas regularidades conductuales) - comprobables como tales en la práctica- o unos proyectos de comportamiento susceptibles de llegar a predominar en sociedades humanas reales. Dichas exposiciones fijan su atención solamente (o muy poco menos) en cómo debieran ser pensados ciertos ideales religiosos o socioéticos. Aunque esas postulaciones resulten ser poco conciliables con las condiciones psicoantropológicas de los tipos de preferencias humanas en general, $y$ por lo demás aquellas suelen hacer enteramente abstracción también de las dinámicas económicas efectivas, empero tales divagaciones son presentadas académicamente a título de verdades apodícticas.

Semejante efecto discursivo se obtiene no solo en virtud de la vasta indeterminación semántica de sus nociones fundamentales [infra § 5], lo cual de por sí habilita la comodidad argumentativa de hacerlas conciliables con muy variadas suertes de interpretaciones contradictorias en cuanto a las prácticas efectivas. Por añadidura, ese orden de aserciones («autenticidad», «deber», etc.) son inmunizadas de antemano en tales discursos, pues ahí se formulan en clave de dogmas supraordenados a priori frente a toda cuestión de falsabilidad empírica. Tales propuestas abstractísimas se autosustentan en-sí-y-por-sí en los universos semánticos de sus teorizadores, estimen lo que estimen de veras las gentes comunes «de carne $y$ hueso», hagan lo que hagan estas mismas en esos respectos.

Entonces es cuestión de mantener confinada la atención dentro de las paredes mentales de unos «mosquiteros» constituidos por ciertos entia lingüísticos de «embrujo» (Wittgenstein ${ }^{24}$ ) académico, sean unos u otros según las modas doctrinarias adoptadas. Esos verbalismos $^{25}$ biensonantes vienen a parar, por cuanto hace a la filosofía social, a pregonar variantes, sean estas cuales fueren, que corresponden a la estructura mental básica de un tipo general de teorizaciones escapistas que aun el propio Marx supo detectar:

«El enemigo más poderoso del humanismo real ... es el espiritualismo o idealismo especulativo, que suplanta al hombre individual y real por la "Autoconciencia" o el "Espíritu"....»"

24 «La filosofía es una batalla contra el embrujamiento (Verhexung) que sobre nuestro entendimiento ejercen los medios de nuestro lenguaje» [Wittgenstein, 1953, \# 109 in fine]; «¿Cuál es tu finalidad en la filosofía? Enseñarle a la mosca la salida de la botella-cazamoscas (Fliegenglas)» [ibíd., 1953, \# 309]. Para ambas citas: trad. E.P.H.

$25 \quad$ «... lo que Bertrand Russell denominó falacia del verbalismo, o sea, utilizando sus propias palabras, "tomar las propiedades de las palabras por las propiedades de las cosas"» (Castilla del Pino, 1974, p. 160 -curs. E.P.H--).

26 Crítica de la dialéctica y la filosofía hegelianas en general, Prólogo (Marx y Engels, 1967, p. 47). 
Efectivamente, para regir las cuestiones de «felicidad» en la manera cómo son encaradas por Žižek se «suplanta al hombre individual y real». Este que anhela sobre todo poseer el último modelo de celular y poder dedicar la mayor cantidad posible de horas del día a intercambiar mensajes por WhatsApp, el que vive pendiente de los resultados del fútbol o de las estrellas del espectáculo; ese cuya principal preocupación es ganar la mayor cantidad de dinero posible, el obsesionado en escalar puestos de mando en la empresa privada o en la política u ostentar galardones sociales: ese que... La «suplantación» tiene lugar por unos cultos a las preferencias discursivas del autor ( $y$ de quienes gusten reciclar los mismos o similares oratorios). A continuación extractaré unas muestras [mediante cursivas destaco algunos de los términos más señaladamente vago-persuasivos]:

- procurar «la vida humana de libertad y dignidad (lo cual) no consiste únicamente en la busqueda de la felicidad» [41:40], «encontrar una causa significante más allá de la lucha por una supervivencia placentera» [41:50];

«la principal carga es la libertad en sí misma» [42:10];

- «nos son prohibidas las excusas baratas por no hacer nuestro deber», necesitamos brindar «prueba de autenticidad», «nunca presuman que su sufrimiento es en sí mismo una prueba de autenticidad» [42:15];

corresponde evitar la «autodenigración» $y$ el consiguiente «lucro» [46:15], procurar «las verdades (que) yacen afuera en las cosas que hacemos» [49:45];

evitar «degradación moral, promiscuidad sexual, hedonismo del consumidor» [50:05];

hacer a un lado «la envidia, el resentimiento», pues ello «me hace actuar en contra de mi propio interés» [52:40]; «enfocar mi vida en problemas creativos más importantes» [55:30], «necesitamos una figura de maestro que nos empuje fuera de la inercia ... [maestros que] obligan a ser libres ... la función primordial de un auténtico maestro es literalmente despertarnos hacia nuestra libertad» [1:00:25].

Es verdad que, aun con toda su vaguedad, alguna idea puede uno hacerse, como intelectual, de hacia dónde apuntan grosso modo esos consejos sobre ciertas actitudes morales, bastante mencionadas en la literatura durante el correr de los siglos. Aun por mi propia parte no estoy en contra de que ellas sean alabadas, sino todo lo contrario, en cuanto puedan marcar diferencias de conducta reales. La mistificación en que incurren planteamientos al respecto como esos de Žižek reside en dar por descontado que, porque semejantes ideales intelectualistas se le presenten como tan sublimemente deseables a él mismo y a unos cuantos académicos más (hasta podría contarme entre ellos), sería ni más ni menos que de esa manera cómo resulte posible resolver los principales problemas sociales en la práctica: ifalacia intelectualista! ${ }^{27}$.

[Nota.- Por cierto, mi comentario no pretende dar a entender que recomendaciones de conducta como esas de Žižek carezcan de validez en virtud de responder a gustos que son los de unos círculos muy minoritarios de personas. Los exámenes del tipo aquí practicado no se dirigen a acreditar o desacreditar en cuanto al plano valorativo los ideales en cuestión, ni por ser mayoritarios ni por ser minoritarios, sino que procuro llamar la atención sobre el confusionismo cognitivo de encarar estas cuestiones con base en falacias intelectualistas como las proclamadas por dicho autor. - Y no menos cierto es que, en numerosas prácticas comunes de los medios universitarios, ni aun los propios intelectuales suelen dejarse atar efectivamente por esos ideales que sus books

$27 \quad$ «What may conveniently be described as the Rationalist Fallacy in political thinking: namely the assumption that human beings largely act in politics upon rational motives and trains of intelligent reasoning. We in our time, alas, know what fatuous nonsense this is" [A. L. Rowse: en Wallas, 1962, p. 1 in fine y s. (aquí con curs. E.P.H.); no puede ser más recomendable ese esclarecedor librito]. 
proclaman en do de pecho. También ahí reinan a sus anchas los juegos de intrigas «palaciegas» - no menos que en cualquier otra entidad pública o privada - para obtener o conservar puestos de mando, la protección «a como haya lugar» de sus ventajas propias por parte de férreas cúpulas académicas, imposición de censuras a enfoques heterodoxos, mimetización del discurso hacia complacer ideologías hegemónicas («corrección política»), etcétera.]

\section{ESPECIES DE CUESTIONES CONSIDERADAS}

He reconocido, de antemano ${ }^{28}$, que lo principal para considerar no tiene por qué concentrarse en aquilatar si los contenidos de las exposiciones presentadas en esa ocasión se hayan ajustado ceñidamente al título establecido, lo llamado «felicidad» (sea esto lo que fuere). A pesar de la señalada endeblez de información y de reflexión que las observaciones de Žižek tienen para ilustrar sobre conocimientos acerca de cuestiones que suelen ser mentadas por esa palabra, acaso dichas observaciones pudieran arrojar luces sobre aspectos sociales muy importantes señalables sin recurrir a dicho término. En el presente numeral haré total abstracción de si las cuestiones sustantivas abordadas por Žižek quepan o no bajo el rubro «felicidad». Fijaré la atención directamente en distinguir qué tipos de cuestiones fueron las «debatidas» allí y procuraré discernir en qué consistieron los desacuerdos al respecto si los hubo.

\section{a) BASES PARA EL ANÁLISIS RACIONAL DE ESA TEMÁTICA ${ }^{29}$}

Acerca de los asuntos tratados en esa ocasión corresponde distinguir entre los siguientes grandes renglones (tales diferenciaciones no

28 Supra, $\$ 1$ in limine: «Nota».

29 Estas precisiones responden a nociones metodológicas básicas expuestas en estudios como los que se indican (infra) en las nn. 45, 46, 49, 50. [Al respecto habrá ocasión de efectuar aun aquí mismo algunas puntualizaciones complementarias: Sec. B.]. fueron efectuadas allí por Žižek, tampoco las indicó Peterson):

a) Afirmación o negación de hechos: çhubo discrepancias sobre si existen, y cómo, ciertas señaladas regularidades socialconductuales o psicológicas, allí afirmadas explícita o implícitamente?

b) Aceptación o negación de imputar determinadas terminologías (sean filosóficas, éticas, de teoría social u otras) para identificar a tales o cuales referentes (reales o imaginarios), o en cuanto a cómo esas verbalizaciones hayan sido o deban ser interpretadas (históricamente o en la

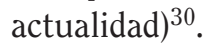

c) Señalar influencias efectivas de ciertas ideas sobre la producción y configuración de otras ideas, «contagios» que han emitido unas de ellas para determinar contenidos de otras subsiguientes: es indagar sobre relaciones semánticas en la historia de las ideas, también sobre cuál interpretación sea respectivamente la «verdadera» (si cupiera presuponer que exista tal) para ciertos escritos de determinados autores o para una corriente de estos.

d) Indicar (describir; afirmar o negar) la existencia de ciertas relaciones causaefectos prácticos que dichas ideas (todas $o$ algunas) ejercen, o han ejercido o están en condiciones de llegar a ejercer, como factores reales (i.e., causas o concausas) para ocasionar determinados fenómenos sociales como conductas colectivas [unas del renglón a)].

e) Aceptar o impugnar ciertos juicios valorativos, ya sean categóricos o instrumentales, sobre lo considerado en cualquiera de los cuatro puntos anteriores.

f) Resultado fundamental ( $\alpha$ ): consejos para la vida ética personal.

g) Resultado fundamental ( $\beta$ ): consejería en materia de acción política.

$30 \quad$ Esto es, conocer los «esperantos» en cuestión [infra $\$ 7]$. 
Salta a la vista que, sean cuales fueren las respuestas consideradas en cada uno de estos siete rubros, difieren los tipos de pruebas requeribles para aceptar o negar la respectiva veracidad o plausibilidad de lo sostenido en cuanto a ello. O bien, se puede sostener que tales o cuales de esas afirmaciones (¿o todas o casi todas?) son tan palmarias que no hace falta ofrecer «prueba» alguna para sustentar su credibilidad: vale decir, que si alguien expresa dudas al respecto no puede deberse sino ya sea a su propio desconocimiento abismal sobre el asunto o simplemente a carencia de las mínimas destrezas intelectuales para abordarlo [descontando que él no lo hace por capricho o animus jocandi, o unos inconfesables motivos de otro orden (p. ej.: acaso mera vanidad académica personal, o el acoplamiento a una carta de fe doctrinaria necesaria para ocupar posiciones en ciertos cenáculos profesorales, o ...)]. En esta segunda hipótesis de trabajo, no cabe poner en duda nada de las afirmaciones sustentadas así, no queda más que reverenciarlas a ellas por sí mismas o en virtud de quién es su autor.

Cargaré con la irreverencia de no sumarme a esa segunda hipótesis. Voy a partir del supuesto ( $j . .$. mas vaya Dios a saber si es verdad!) de que Žižek no entienda negar a priori que sus propias afirmaciones puedan estar sujetas a la presentación de «pruebas» aptas para sustentar su credibilidad, en cuanto a aquellas entre esas aseveraciones cuya veracidad sea puesta en duda total o parcialmente. Es cierto que, aun así, pueden caber discrepancias también sobre, justamente, cuáles «pruebas» concretas o qué criterios generales de verificación sean adecuados para juzgar sobre los puntos en cuestión. Pero incluso en este último caso, discrepancias sobre esos criterios mismos, en la discusión sobre los temas de fondo debiera quedar claro al menos:

- Cuáles aseveraciones principales de los debatientes se contradicen entre sí, total o parcialmente.

— Qué «pruebas» o «contrapruebas» empíricas ofrece cada quien con respecto a las afirmaciones controvertidas, sean o no sean consideradas pertinentes esas pautas de «prueba» por unos u otros auditores. Cuáles afirmaciones controvertidas desde un lado, en el de enfrente se entiende que no necesitan ser confirmadas mediante «prueba» alguna; quiere decir que estas últimas son enunciadas de este lado como verdades auto-evidentes (p. ej.: es así cuando se invoca un juicio de valor en el modo categórico, o sea, presuponiendo axiomáticamente que su pertinencia no depende de condicionamiento empíricocontingente alguno, a diferencia de los juicios de valor instrumentales ${ }^{31}$ ) [sin perjuicio de que en tales controversias no se cuestione en forma expresa la veracidad de unas regularidades empíricas que de modo unánime reconocen los científicos de la rama correspondiente].

\section{$\beta$ LOS TIPOS DE INTERROGANTES}

Paso a dejar anotadas unas aforísticas puntualizaciones básicas en donde diferencio entre lo pertinente para respectivamente cada uno de los siete rubros de cuestiones cardinales enumerados en el apartado precedente:

- [a)] la existencia de qué hechos — ciertas regularidades sociales o psicológico-individuales - reconocen en común ambos debatientes y sobre cuáles discrepan;

[b)-c)] ¿es esa una indagación centrada sobre todo en aclarar ciertas cuestiones de historia de las ideas (interpretación verdadera acerca del «marxismo»y señalar derivaciones doctrinarias, detectar influencias de algunas concepciones sociales para determinar contenidos de otras subsiguientes) $y$ asimismo saber cuáles aspectos de los hechos-[a)] corresponda denominarlos mediante tales o cuales entre esas ideas?

- [d)] cómo ha funcionado, o funcionará probablemente, la efectividad práctica de las ideas consideradas;

- $\quad[\mathrm{e})$-g)] valoraciones y consejos.

$31 \quad$ Infra: $:$ n. 36 . 
a) Hechos. No se hacen presentes discrepancias de este orden: ni en cuanto a hechos externos (unas $\mathrm{u}$ otras conductas sociales) ni internos (caracteres psicológicos), ni particular-individuales ni colectivos, ni pretéritos ni actuales. No veo que Žižek haya negado la existencia de ni uno solo de los hechos sociales indicados en la intervención inicial de Peterson ${ }^{32}$.

b) Terminologías. Hay calificativos que usa un expositor y no el otro; pero ninguno de ellos objeta la terminología del otro, salvo por cuanto Žižek lo hace para fijarle contenidos teoréticos específicos a la palabra «marxismo». Más aún, hasta tienen lugar unos asentimientos expresos para valerse de ciertas calificaciones característicamente ético-emocionalizantes («gracia», «autenticidad», etc. ${ }^{33}$ ).

c) Historia de unas ideas políticas. Se pusieron de manifiesto discrepancias en cuanto a cuáles sean los verdaderos contenidos en programación política del pensamiento de Marx (visto en su conjunto) ${ }^{34}$; pero en la segunda parte del «debate», Peterson reconoce no ser experto acerca de ello ${ }^{35}$.

d) Practicidad social. En su exposición inicial, Peterson formula afirmaciones netas con respecto a las influencias reales que las ideas marxistas han tenido $y$ tienen (real o supuestamente) sobre los aconteceres sociales inspirados (real o supuestamente) en tales pautas de acción. Por su parte, la exposición inicial de Žižek deja fuera de foco esa cuestión, salvo si acaso al decir: «... lo admito por completo, el fracaso del proyecto comunista del siglo XX» [1:02:45].

32 Téngase presente la advertencia de la n. 4 (supra).

33 Cfr. supra: a la altura de las nn. 17 y 18.

34 Téngase presente lo señalado más atrás: $\$ 3 . \beta$ ).

35 «¿Dónde encontraste la información...? (...) ¿... donde está realmente el elemento marxista en...?» [1:46:30]. «¿...por qué les llamas...?» [1:45:00]. Referencia a que Foucault no estaba de acuerdo con el marxismo [1.54:30].
La cuestión propia señalada por Peterson no queda para nada contestada mediante esta última afirmación, esto es: ¿contribuyeron decisivamente ciertas ideas básicas de Marx para determinar tal «fracaso»?; ¿qué posibilidades reales hay de que ya no pase así cada vez de que justamente tales ideas sean utilizadas como guía por los dirigentes de regímenes en el futuro? Aun si se aceptare que Marx fue malinterpretado al imputarle dichas ideas, esto no altera para nada la cuestión práctica: llámesele o no «marxismo» a aquellas mismas, lo principal es fijarse en si estas tienen o no tienen los efectos reales señalados por Peterson.

Žižek se escapa por la tangente sobre este asunto - irealidades políticas de los regímenes «marxistas»! - al concentrarse en encararlo como cuestión de conocer suficientemente la exégesis históricodoctrinaria invocada [supra punto c)]. En efecto, él no discrimina entre marxismoliteratura y marxismo-realidad [supra $\S$ 2.(3)]. Queda así completamente a un lado la necesidad de considerar pruebas empíricas sobre viabilidad práctica (racionalidad instrumental) de lo pregonado por Žižek, sea o no sea que a esto mismo se le llame «marxismo».

e) Valoraciones. Desde luego, los exámenes sobre cuestiones sociales no pueden estar desprovistos de basarse en tales o cuales juicios de valor, explícitos o implícitos. La diferencia la hace el cómo sean explayadas esas valoraciones: si estas son o no son distinguidas de las comprobaciones estrictamente empírico-descriptivas (sin perjuicio de reconocer relaciones entre las segundas y las primeras), ver si es contemplada la diferencia fundamental entre juicios de valor categóricos e instrumentales ${ }^{36}$, examinar si estos últimos

$36 \quad$ Sobre la diferencia -jfundamentalísima!- entre juicios de valor categóricos y juicios de valor instrumentales, cfr. Haba, 2006, Sec. C.III.5 (p. 310 y ss., «Recurso a las ciencias sociales para fundamentar conclusiones normativas») [más amplio en 2012, Sec. E.III]. Mucho importa también no perder de vista la capital distinción entre cuestiones explicativas y cuestiones normativas (Vaz Ferreira, 1963, cap. homónimo). 
son o no sometidos a verificaciones científicas, etcétera.

En el presente caso, los participantes no adoptaron esas cardinales precauciones analíticas; tal vez no era de «buena onda» hacerlo ahí, máxime atendiendo a la variopinta composición de las anotaciones que esparció Žižek. De todos modos, aun haciendo a un lado la cuestión metodológica, no hay contradicción entre los dogmas axiológicos presupuestos de uno y otro lado, verbalizados principalmente mediante «fórmulas» como las señaladas más atrás: «libertad y dignidad», «causa significante» 0 «sentido», «autenticidad», y demás ${ }^{37}$.

f) Ética personal. En cuanto a cómo debiera cada persona conducir su vida individual, el acuerdo entre Žižek y Peterson es inclusive bastante expreso ${ }^{38}$, hasta concuerdan ambos enfáticamente en pregonar determinados etiquetados lingüísticos al respecto: «autenticidad», «gracia», etc. ${ }^{39}$.

$g_{1}$ ) Consejería política (i): Peterson. En su primera exposición, no puede quedar más claro que él considera adecuado mantener la economía de tipo capitalista: cada quien ha de tratar de arreglar sus dificultades personales dentro de ese marco, en la medida de lo posible mediante procesos de concienciación personales. Luego Peterson se plegó a que, en vez de examinar eso en función de los hechos destacados en dicha exposición, la conversación se haya ido por las «ramas» [supra: puntos $b), c), e), f)$ ]. - En esas divagaciones secundarias, donde ambos participantes se orientaron sobre todo a compartir similares expresiones de buenos deseos, no es que haya sido negada, ni aun por parte de Žižek, la verdad de aquellos hechos ni las respectivas inferencias de orden socioempírico subrayadas en la exposición inicial de Peterson; a esa altura del «debate», ambos se satisficieron con sencillamente hacer abstracción de todo ello.

$\mathrm{g}_{2}$ ) Consejería política (ii): Žižek predicador (un repertorio de socio-belletrismos). Si bien Žižek admite que el «mercado capitalista hace grandes cosas» [1:10:00] y hasta reconoce «el fracaso del proyecto comunista del siglo XX» [1:02:45], cabe pensar que ahí él vino a proponer otra «cosa» -ise supone que estamos ante un «debate»! - que aquello señalado por Peterson. Presuntamente sería cuestión así de implementar soluciones políticosociales alternativas; estas serían opuestas, por lo menos en muy buena parte, a lo que ofrece al respecto el capitalismo conocido. Pues bien, ¿cómo saber en que consistan tales alternativas? Se haría extensísimo detenerse a analizar una por una el salpicón de pontificaciones doctrinarias reunidas en esa ocasión por Žižek; a título indicativo, me limitaré a entresacar algunas de las «soluciones» propuestas por él allí. Invito a que cada lector ejerza su propia perspicacia en lograr (me confieso incapaz de hacerlo yo) inferir cuáles serían tanto las correspondientes medidas económicas y las ordenaciones políticas correspondientes, como así también las consecuencias sociales reales de todo ello. He aquí, pues, unas muestras típicas de este belletrismo:

«...crear el espacio para que tantos individuos como sea posible desarrollen sus diferentes potencialidades» (54:15) [seguramente, Dios y Žižek están enterados de qué sea lo «posible» y cuáles medidas prácticas estarán disponibles para lograrlo].

- En «una democracia... la decisión última debería estar con [traducción más adecuada: depositada en] todos nosotros» (1:00:00) [seguramente, Dios y Žižek saben cuáles son las reglamentaciones-modelo llamadas a reemplazar las formas usuales en democracias representativas conocidas, para que 
en adelante «todos» conformen el cuerpo colectivo que tome la «decisión última» en cada caso].

- «...deberíamos actuar a larga escala de forma colectiva» (1:04:30) [ichocolate por la noticia!... pero, ¿cuál forma «colectiva?: Dios $y$ Žižek están al tanto].

- Hace falta «...un capitalismo global con rostro humano» (1:09:00). Esto que «se necesita es ... en todas las esferas que afirmo: ecologismo, control digital, la unión del mundo. (...) El mercado capitalista ... tiene que ser de alguna forma limitado, regulado, etc.» (1:10:00); «... el mercado ya está limitado, pero no en la forma adecua$d a$, para decirlo ingenuamente» (1:10:00); «creo que la autolimitación del capitalismo es necesaria» (1:25:00) [... vayan nuestras más devotas plegarias dirigidas a obtener que Žižek, o acaso algún Maestro ${ }^{40}$ dotado de sapiencia supracientífica similar, esté disponible para encabezar el comité político universal encargado, por común acuerdo entre los gobernantes de los países del mundo, de organizar justamente eso].

- Y al fin de cuentas, si algo de todo lo anterior no queda del todo claro... jeureka!: «En tales tiempos de urgencia, cuando sabemos que debemos actuar, pero no sabemos cómo, pensar es necesario, quizá deberíamos cambiar un poco» (1:06:15).

Con respecto a nada de ello se ofrece prueba empírica alguna - ifaltaba más! - por cuanto concierna a su eventual viabilidad práctica. [En la Sec. D habrá ocasión de considerar algunas otras letanías por el estilo].

40 Cfr. la última cita del grupo indicado en la n. 6 (supra). $\left.\mathrm{g}_{3}\right) \quad$ Consejería política (iii): Žižek dubitativo. Parece que hasta al propio Žižek no se le ha pasado del todo desapercibida la carencia de practicidad de su poemario. Para algunas cuestiones llega a reconocer: «... admitiendo que estamos en un profundo lío, no hay una solución democrática simple aquí...» [1:05:20]. Más aún, al fin de cuentas termina lavándose las manos en cuanto a afirmar la viabilidad de las maravillas sociales que nos había venido pregonando antes:

«Entonces yo sólo veo problemas, soy un pesimista $y$ no soy radical ... no creo en la bondad humana...» $[1: 36: 50]$. «Entonces una conclusión pesimista: ... probablemente seguiremos deslizándonos hacia algún tipo de apocalipsis ... hay luz al final del túnel ... es probablemente otro tren viniendo hacia nosotros» $[1: 10: 00]$.

Notable descubrimiento. Y sobre todo: iqué formidable acopio de evidencia empírica raramente difundida $y$ de inéditas inducciones teorético-sociológicas iluminadoras descubiertas justamente así!

[B]

\section{PUNTUALIZACIONES METODOLÓGICAS COMPLEMENTARIAS ${ }^{41}$}

Nosotros nos limitamos simplemente a preguntar. «¿qué quieres tú decir propiamente»? A cualquiera, quienquiera sea, le hacemos esta pregunta: "¿cuál es el sentido de tu discurso?». A la mayoría, tal proceder los saca completamente de balance. Mas esto no es culpa nuestra; nosotros preguntamos, con toda honestidad, y no queremos tenderle trampas a nadie ${ }^{42}$.

Moritz Schlick (como se citó en Koch, 1977, p. 8).

41 Las observaciones incorporadas en esta Sección se asientan en unos elementales saberes de metodología que son básicos para efectuar estudios realistas en ciencias sociales [véase, p. ej., los sitios a que remite la n. 29 (supra)]. 
Las distinciones entre tipos de rubros conceptuales efectuadas en el numeral anterior [§ 4] responden, desde luego, a unos presupuestos metodológicos de «higiene» intelectual para organizar el pensamiento acerca de las cuestiones sociales ${ }^{43}$. La engañosidad de aproximaciones como esas de Žižek resulta señaladamente menos palmario advertirla si pasan desapercibidas (como ocurrió con la generalidad de los comentarios al respecto en YouTube) las básicas indistinciones entre categorías de conceptos, $y$ en general las colosales indeterminaciones lingüísticas, que conforman lo expuesto ahí por ese autor.

Ahora bien, el hecho de que juegos de lenguaje como los de Žižek resulten tan propicios para «seducir» ${ }^{44}$ el pensamiento de wishful thinkers en medios universitarios se asienta también, además de responder vertebralmente a fortísimas fijaciones de emocionalismo escapista, en dos típicas celadas lingüísticas capitales: la habitual precomprensión, cultivada por doquier (no solo en el pensamiento vulgar y no poco a menudo en estudios de teoría social), de asumir sin más «La Superstición del Único Significado Verdadero» + el echar mano de tales o cuales «fórmulas vacías» muy prestigiosas (señaladamente habitan en discursos políticos, jurídicos o filosóficos).

$\mathrm{Al}$ recurrir como eje de seducción a estos dos órdenes de expedientes retóricos, así el abordaje queda encerrado en unos pronunciamientos que, justamente por girar en torno de tales ficciones semánticas, se autopresentan de antemano como exonerados de someterlos a contrastaciones de orden factual propiamente dichas. A esos asuntos se les exime de poder ser

43 Desde luego, no suele indicarse en forma expresa el respectivo significado en las palabras que acostumbramos usar, habitualmente ello está implícito de por sí en la comunicación lingüística para el auditorio encarado. Mas también es cierto que no poco a menudo cumple echarlo de menos en controversias centradas sobre términos claves de discursos filosóficos, de ciencias sociales, jurídicos, etcétera. Esto último se dio también en el presente caso, señaladamente en los planteamientos de Žižek.

Supra: n. 24. «testables» mediante métodos de control acreditados en las ciencias sociales empíricas. Esas son maneras de inmunización discursiva [cfr. Albert, 1973]. Todas las ideologías políticas, sean de la dirección que fueren, obtienen muy eficaces efectos persuasivos de sus respectivas in-distinciones propagandísticas.

\section{PALABRAS, PALABRAS...}

One might say of such words that they serve as pegs: it's marvellous what a lot of things you can put on them.

Waismann, (1951, p. 136).

a) ¿HAY QUE ACTIVAR EL SIGNIFICADO VERDADERO?

He considerado fundamental distinguir con escrupulosidad entre diferentes sentidos posibles de los términos básicos [supra §§ 2 y $3]$, para poder estar de veras en condiciones de localizar empíricamente dónde y cómo identificar los alcances prácticos de las indicaciones sobre comportamientos humanos que se efectúan en enunciados donde esas palabras se incluyen a título de guía capital. ¿Son «ociosas» semejantes distinciones? Lo serían en caso de que, contrariamente a cuanto salta a la vista en las experiencias sociales cotidianas e incluso mediante las controversias académicas sobre ello, se dieran ni más ni menos que las condiciones siguientes.

a) Si todas (o casi todas) las personas, en caso de preguntarles si son «felices» 0 qué les haría falta para serlo, contesten (sinceramente) señalando más o menos las mismas suertes de «cosas» concretas como objeto de sus deseos personales ubicables bajo las maneras cómo comprenden ellos mismos dicho término.

b) Si todos (o casi todos) los que se proclaman como creyentes en lo que llaman «marxismo» están normalmente de acuerdo en propugnar iguales (o muy poco menos) soluciones específicas (i.e., intersubjetivamente distinguibles de cualesquiera otras) sobre las cuestiones sociales que se planteen. Vale decir, si frente a tales cuestiones basta con 
preguntar a uno o dos «marxistas» su opinión al respecto, para tener muy altas probabilidades de acertar en cuanto a qué recomienden concretamente sobre eso mismo todos o casi todos los demás autodenominados «marxistas».

c) Si tanto quienes están a favor como quienes están en contra de lo que llaman «capitalismo», todos ellos (o casi todos) se refieren a los mismos hechos (cuya existencia no ponen en duda ni los unos ni los otros). Esto por más desacuerdos que entre los primeros y los segundos pueda haber sobre cuáles sean las causas y unos efectos laterales de todos o parte de esos hechos mismos; $y$ aun sin perjuicio de que entre ambos bandos haya cualesquiera desacuerdos en cuanto a unas categorizaciones axiológicas («alienación», «libertad», etc.) de que respectivamente hagan objeto a esas situaciones de hecho.

Mas habrá quienes cuestionen, justamente, si preguntas de esa índole y en general los cuidados por la precisión científica son de veras pertinentes aquí, atento a cómo entiende enfocar los asuntos el propio Žižek. ¿Es sensato, después de todo, aplicar tales criterios para abrir juicio sobre aproximaciones como esas? Da la impresión de que en estas se tiene por sobreentendido que No vale la pena discriminar - ¿para qué?- entre sentidos diferentes en cuanto a las palabras claves empleadas allí. Comentaristas como Žižek, y aun ciertos pensadores de talla, suelen abstenerse de plantear preguntas semejantes. No falta quienes consideran que preocuparse por la precisión es pasar de costado sobre las cuestiones «humanas» en sí mismas; ellos estiman que semejantes escrúpulos lingüísticos resultan engañadores (en términos de Hegel: sería rendir culto al «entendimiento», en vez de superarlo mediante el pensamiento «dialéctico»), o que al menos eso viene de sobra.

Tales abordajes parten de la base, implícitamente, de La Superstición del Único Significado Verdadero ${ }^{45}$. A Žižek no se le cruza

$45 \quad$ «... la Superstición del Único Significado Verdadero - tal como la ha denominado I. A. Richards- por el pensamiento, al parecer, que términos como aquellos que emplea como categorías de identificación fundamentales para examinar las cuestiones sociales se entienden de maneras muy variadas. Está convencido, al parecer, no sólo de que él mismo sabe cuáles situaciones generales bien determinadas $y$ hechos concretos corresponde subsumir bajo dichas calificaciones respectivamente, como da por descontado también que no es sino eso mismo lo que ubicarán bajo tales términos los hablantes en general, o que en todo caso lo harán justamente así quienes se enteren de cuanto él diga ahí. En cambio, yo pongo sobre el tapete unas preguntas que en perspectiva extra-analítica son no poco desaconsejables. Sucumbo al desatino (visto desde perspectivas esencialistas) de considerar que corresponde someter a examen si poseen algún Único Significado Verdadero respectivo esos términos claves para los cuales Žižek da por descontado, al parecer, que en-sí y por-sí son no menos indubitables que inmarcesibles.

Es verdad que está abierta la posibilidad de elegir, sea explícita o implícitamente, una definición estipulativa con respecto a cada término básico, escogida de acuerdo con los respectivos gustos doctrinarios de cada autor, entre las muchas posibles dentro de sus variados ámbitos semánticos. ¿No corresponde reconocerle a Žižek la libertad intelectual de acogerse, también él, a ese recurso lingüístico? Obviamente, la respuesta no puede ser negativa, como cuestión de principio. Solo que, entonces importa sacar a luz tales definiciones estipulativas, sean ellas cuales fueren, para dejar circunscrito de QUÉ se entiende hablar al respecto, cuando esto no sea simplemente obvio para el contexto de elucidaciones dado.

lo cual puede tener consecuencias muy serias en cualquier campo del saber, $y$ es fatal para cualquier pretensión de adelanto en el campo de la ética» [Stevenson, 1971, p. 86]. Y véase la capital monografía de Robinson, 1972: esp. cap. vi (p. 149 y ss., «Real Definition»). También es fundamental: Vaz Ferreira, 1963, cap. «Cuestiones de palabras y cuestiones de hecho». 
$\beta)$

FÓRMULAS VACÍAS PSEUDONORMATIVAS

Términos dudosos, indeterminados, que no guardan correspondencia con lo concreto. Este es el límite extremo de las derivaciones verbales, las cuales así llegan a ser una simple música de palabras (musica di parole). De poco sirven para el vulgo, el cual entontecido y estupefacto por la extrañeza de los vocablos se queda boquiabierto, supone que estos esconden quién sabe qué misterios;

la mayoría de esos términos son para uso y consumo de los metafísicos, quienes rumiándolos continuamente terminan por figurarse que son cosas reales ${ }^{46}$. Pareto (1978, p. 307: § 631).

Hay dos clases de propuestas sociales que suelen autoidentificarse como soluciones «alternativas» o «progresistas». Unas pueden ser bastante precisas: p. ej., expropiación estatal de los medios de producción (Marx). Otras, en cambio, consisten en unos ensamblajes de emblemas lingüísticos que, si bien cada uno de estos es de lo más biensonante, no indican ninguna medida concreta.

En esta segunda especie se ubican cabalmente las divagaciones del tipo que cultiva Žižek. La concreción práctica de estas leyendas políticas, supuesto que fueran invocadas por protagonistas sociales con influencias públicas prácticas considerables, no puede menos que depender de cómo prefieran entenderlas $y$ hacerlas ejecutar unos individuos concretos. Son aquellos que, en determinada colectividad, disponen o consigan llegar a disponer del poder efectivo para imponer allí sus propias preferencias, sobre cómo organizar (jerarquías de mando, órdenes de privilegios, etc.) los esquemas básicos generales según los cuales resultan distribuidos allí los bienes. Las invocaciones a sean cuales fueren unos vaguísimos emblemas como los conjurados por Žižek desempeñan,

46 Aquí trad. E.P.H. En cambio, la «forma di ragionamento, che mette in luce i caratteri relativi, soggettivi, non-logici dei principi, ripugna ai metafisici, ai teologi ed anche a moltissimi studiosi dei fatti sociali; essi cercano l'assoluto, l'oggettivo, il logico e lo trovano [japarentemente!] sempre con l'uso di vocaboli indeterminati e di ragionamenti difettosi (derivazioni, cap.VII)» [ob. cit., p. 88: § 175]. de hecho, el papel de «encantamiento» semánti$\mathrm{co}^{47}$ característico de esas expresiones lingüísticas que en estudios de crítica analítico-realista de las ideologías consiguen ser des-cubiertas identificándolas como: fórmulas vacías pseudonormativas, ciertas expresiones típicas cuyo sentido dispositivo de regulación se presta a múltiples suertes de interpretaciones divergentes.

Por supuesto, nadie entenderá estar en contra de finalidades como «libertad y dignidad», «autenticidad», «el bien común», «democracia». Qué consecuencias se saquen de esas palabritas en los hechos ${ }^{48}$... ¡harina de otro costal! Aquellas expresiones son todo lo multívocas que hace falta para no comprometer a nada específico, en discursos de orden político, moral, jurídico y otros. Se emplean para adornar los programas de conducta social más variados ${ }^{49}$. En virtud justamente de ese su

$47 \quad$ Supra: n. 24.

48 Para muestra, un botón. Seguramente las dirigentes políticas españolas, Sras. Carmen Calvo y Cayetana Álvarez de Toledo, no alimentarán duda alguna de que los tribunales de justicia deben amparar la «libertad y dignidad» de las mujeres. Pero, mientras la primera extrae la consecuencia de que, para lograr justamente eso, es indispensable [«Las mujeres tienen que ser creídas sí o sí, y siempre»: http://www.outono.net/elentir/2018/12/13/ carmen-calvo-ha-enloquecido-asi-lo-indica-suburrada-sobre-la-presuncion-de-inocencia/] la disposición que en la actual Ley Integral de Violencia de Género deja de lado allí el clásico principio penal de presunción de inocencia para la mitad de la población de ese país, la segunda, en cambio, propone suprimir tal disposición justamente.

49 Cfr.: Degenkolbe, 1965; Topitsch, 1960, 1966 (esp. pp. 38 y ss., 174 y s.), 1972b (esp. § VI: p. 26 y ss.), 1988 (passim); Haba, 2006, Sec. C.I.4 (p. 197 y ss., «Fórmulas vacías pseudonormativas») [0 2012, Sec. D.II.3]; y véase Pareto (supra: n. 46). Abundante cantidad de ejemplos en Haba, 2016 , \# 259-262 (p. 245 y ss., «Fórmulas vacías en su función de ideología») + 332 (p. 357 y ss., «Del catálogo "Saludos a la Bandera"»). Para otras explicaciones sobre la naturaleza lingüística de las «fórmulas vacías» (Leerformeln) en general y las pseudonormativas en particular, también con referencias en especial al uso de ellas en el Derecho Constitucional y el Derecho Administrativo, cfr. Haba, 1986: § 17.I (p. 246 y ss., «"Ámbito lógico", ámbito social", "fórmulas vacías"») y los estudios indicados de los autores que se señalan ahí. 
carácter de «vacías», o semivacías, resulta de lo más cómodo bendecirlas y aceptarlas... isaludos a la Bandera!: «el Bien» y «el Mal», la «justicia» $y$ la «equidad»; el «bien común» o el «interés de la colectividad» o la «utilidad general»; lo «correcto», lo «racional» o «razonable», el «equilibrio» o la «proporcionalidad» (estos dos términos no son entendidos ahí en un sentido numérico), lo «adecuado»; «orden» y «anarquía», «moral» e «inmoral», «natural»...50.

$50 \quad$ La polivalencia y manipulabilidad de términos como esos, y otros, es examinada detalladamente en Haba, 2016: esp. Secs. B (p. 29 y ss, «¿Qué significa "justicia"?), C (p. 49 y ss., «Variadas pautas de valor en el derecho») y D (p. 119 y ss., «Tensiones, antinomias»). Véase también exámenes de desmitificación más generales sobre el lenguaje de la política [cfr.: Macdonald, 1951; Weldon, 1953; Debray, 1983], lo cual es extensible también a discursos de la doctrina del Derecho Público [cfr. Haba, 2016: esp. Sec. C.II (p. 74 y ss., «Utilidad social (bienestar general, justicia social) y "bien común" (interés general)»)]. —El pantagruélico caleidoscopio de contenidos de referencia que llevan anejos los usos de tales términos los hace especialmente atractivos también para múltiples suertes de elucidaciones académicas, donde al fin de cuentas ellos suelen ser encarados como objeto de investigación bajo el presupuesto de abocarse a hallar algo así como su definición «real». Así, en renombrados exámenes idealistas acerca de la etiqueta «justicia»: cfr. los estudios de autores como Rawls, Nozick o Sen, y la innumerable literatura secundaria a su alrededor. Por contraposición a tales constructos de la imaginería racionalista, véase los dos capitales análisis realistas (desde luego pasados en silencio por esos tres bestsellers) sobre los usos de dicha etiqueta: Perelman, 1964; Kelsen, 1966; también otros autores han ofrecido exámenes señaladamente lúcidos, terre à terre, que ponen de manifiesto la multivocidad de dicho comodín retórico [p. ej., cfr: Kriele, 1963; Hospers, 1964 (cap 9)]. En cuanto a las definiciones «reales», cfr. Robinson, 1972: cap. VI. [A creaturas de la falacia intelectualista (supra n. 27) como esas de Rawls, Nozick o Sen les son aplicables observaciones analítico-realistas básicas como las indicadas en Haba, 2009; si bien estas últimas se refieren en especial al idealismo de Rawls, en lo básico son pertinentes para aquellos otros dos autores también, y asimismo en cuanto a Habermas (cfr. Haba, 1996); en general sobre el pensamiento "constructivista» en la teorización sobre lo social, cfr. Haba, setiembrediciembre, 2007].
[Por ejemplo.- Palabras como «libertad» o «justicia», si bien ambas conllevan indefectiblemente sentido valorativo-emocional positivo muy fuerte, empero cada una admite múltiples sentidos empírico-descriptivos, muchos de los cuales resultan contradictorios entre sí. Qué sea «justicia» es entendido en al menos seis sentidos descriptivos netamente distinguibles entre sí (cfr. Perelman, 1964). Las indeterminaciones de la idea «libertad» son prácticamente infinitas; a este sustantivo no le corresponde algo así como un designatum general propio, sino que constituye un enlace de relación entre al menos cuatro extremos variables al infinito: «libertad» de quién o quiénes, frente a quién o quiénes, para hacer (o abstenerse de hacer) cuales cosas, y con qué consecuencias efectivas ${ }^{51}$.

Esas expresiones conjugan, en la práctica de sus usos tan variados, tres rasgos distintivos fundamentales. a) Son fuertemente emotivas, suscitan automáticamente la adhesión sentimental de la gente. b) Nadie osa (más aún, por lo general ni siquiera piensa en) declararse en contra de ellas (si bien son objeto de múltiples discusiones cuáles sean o no sus aplicaciones «verdaderas»): son in-discutibles, tanto a los ojos del locutor como de su auditorio, no precisan ni admiten análisis ni prueba alguna para justificar su carácter de ratio suprema. c) Por ser tan extremadamente vagas, de estas formulaciones en sí mismas no es posible inferir específicamente ninguna medida o grupo de medidas definidas; mejor dicho, su letra permite «deducir» las más variadas y contradictorias interpretaciones en la práctica, según las preferencias propias de cada grupo de locutores al invocar esos términos. - Casi todas las nociones fundamentales encomiadas por Žižek cumplen a cabalidad con estos tres requisitos de «vaciedad» 52 .

51 Cfr. Haba, enero-junio, 1992. Véase también Haba, 1976, esp. cap. II (p. 55 y ss., «Concepto de la libertad individual»).

52 Véase, p. ej., en formulaciones reproducidas más atrás: las ubicadas a la altura de las nn. 17 a $21+$ las indicadas en la n. 6 . 
Por el contrario, un enunciado se halla provisto de propiamente algún contenido normativo específico si de su esfera de aplicación él excluye $-y$ esto en forma netamente intersubjetiva- ciertos tipos bien determinados de conductas, actitudes, formas de pensar; o sea, cuando esta formulación permite distinguir en forma inequívoca entre lo que ella señala y cualesquiera otros comportamientos posibles. Pasa lo contrario con palabras como las entrecomilladas un poco más atrás ${ }^{53}$. Acontece a menudo con todo o parte de lo que dice un precepto moral o un principio de teoría política o ciertas clases de disposiciones jurídicas.

No es difícil lograr un consenso verbal para la letra de tales invocaciones, justamente porque, en las prácticas, eso no compromete a nada o casi nada con respecto a cómo intervenir en la realidad social misma. En cuanto se plantea la necesidad de concretarlas en los hechos, ahí son los intereses y las ideologías quiénes determinan, según cuáles de estos o estas logren dominar, cuáles vayan a ser las aplicaciones reales de las fórmulas en cuestión. Los actores sociales que tienen el poder para interpretar esas palabritas simpáticas son quienes deciden, entre las múltiples interpretaciones posibles, lo que esas fórmulas significarán fácticamente. Para tales expresiones caben tantos modos diferentes de aplicarlas, por más que estos resulten total o parcialmente contradictorios entre sí, cuantos sean los grupos de intereses presentes contrapuestos y las ideologías que disputen al respecto, cuando llega el momento de establecer las soluciones concretas denominadas así.

Es verdad que aun estas expresiones no son completamente vacías, pues permiten excluir algunas posiciones muy extremas (p. ej., nadie dirá que la «dignidad» humana consiste en ser sometido a torturas policiales). Pero aquellas soluciones específicas que son objeto de serias discusiones en la práctica, justamente estas son las que tales formulaciones no logran excluir. Los partidarios de cada posición concurrente aseguran, cada una por su propio lado $y$ contra las de enfrente, que son solo aquellos mismos quienes responden al verdadero sentido de la fórmula en cuestión (p. ej.: ¿es «violatorio» de la «dignidad» humana ya sea el capitalismo o los regímenes comunistas?).

Formulaciones por el estilo se encuentran corrientemente en la literatura de adorno que son los Preámbulos de las Constituciones y también en los instrumentos del Derecho Internacional Público, o aun en ciertas disposiciones de leyes. No menos forma ello parte de elucidaciones dirigidas a círculos académicos donde, para acreditar «profundidad» filosófica, es cuestión de no mentar la soga en casa del ahorcado: dejan entre bambalinas qué le importa de veras a los seres humanos corrientes y cómo funcionan insalvables vallas fácticas (psicosociales, económicas, etc.) en las colectividades consideradas.

Sin embargo, cuando términos de esta índole se emplean en contextos sociales netamente determinados, reconocidos por parte de locutores cuyas preferencias políticas (en cuanto al asunto considerado y los respectivos hechos conocidos) son patentes, entonces no hay semejante indeterminación: en cuanto a la situación específica verbalizada así se sabe cuáles son determinadas soluciones prácticas calificadas de esa manera, por estos hablantes. En efecto, las «fórmulas vacías» pueden dejar de funcionar como tales cuando aquellas palabras que poseen dicho carácter en los discursos de proclamaciones general-generalísimas pasan, en cambio, a ser usadas para calificar ciertas situaciones concretas. Esto es: siempre y cuando haya acuerdo intersubjetivo, entre quienes recurren a estas expresiones ahí, sobre cuáles son los hechos o determinadas indicaciones de conducta específicas mentados de esa manera, para resolver los problemas específicos considerados al respecto. En planteamientos como los de Žižek: ijustamente este último NO es el caso!

[Por ejemplo.- Lograr la «libertad» de Venezuela, cuando lo dicen quienes anhelan hacer cesar el gobierno chavista, significa al menos lo siguiente, en este momento: sacar de las prisiones a todos los presos políticos (se sabe quiénes son), efectuar elecciones libres dentro de algunos meses (entendiendo por «libre» las condiciones normales de los regímenes capitalistas occidentales para 
ello y hacerlo ahí bajo control internacional), restablecer la libertad de prensa (en las condiciones ídem), ingreso irrestricto de la ayuda humanitaria. Nada de eso es in-determinado, salvo por cuanto hace a detalles de ejecución secundarios. En cambio, permanece de lo más in-determinado cuáles hayan de ser las medidas económicas específicas que realizarían, supuestamente, la «libertad» del país para recuperarse de la catastrófica situación general en que lo deja el «Socialismo del Siglo XXI»: ¿esas medidas serán principalmente de tipo socialdemócrata (extensión de la burocracia estatal y crecientes cargas impositivas, intervención cada vez mayor de esa burocracia mediante reglamentaciones crecientes para toda suerte de conductas humanas, etc.) o antes bien de orden económico-liberal (restricción de las imposiciones estatales y reducción de impuestos, frenos efectivos para las autoridades, etc.), o una mezcla (¿cuál?) entre ambas especies, o...?].

$$
* * *
$$

No obstante, si bien para las prácticas discursivas sociales generales tales términos son tan vastamente indeterminados, eso no quita que cada hablante sincero pueda saber aproximadamente qué entiende por ello él mismo, como indicación general para determinado tipo de situaciones y posiblemente también en cuanto a unos casos concretos. La «vaciedad» genérica de esas palabras no significa que los propios locutores no tengan claro habitualmente, cada cual en su propia mente, cómo usarlos con respecto a tales o cuales situaciones en que piense cada uno por su propia parte, cuando estas son susceptibles de ser relacionables semánticamente (de acuerdo con usos normales de ese lenguaje) con dichos vocablos.

Ante las invocaciones simplemente generalísimas de esa índole, por más etéreas que sean, los auditores que se sienten tocados por estas quedan convencidos -imuy sinceramente! — de saber bien, cada uno por su lado, cuáles son y cuáles no pueden ser los contenidos específicos que corresponden «de veras» a tales formulaciones. Y lo cierto es que, si bien se mira, cada quien no está propiamente equivocado en cuanto a eso mismo. En efecto, cada uno tiene idea de hacia dónde apuntan, inclusive en la práctica, sus propias indicaciones normativas, entiende saber cómo resolver eso si los asuntos respectivos fueran puestos en sus propias manos. Nadie alberga dudas sobre cómo califica él mismo, designándolo justamente mediante la «fórmula» dada, tal o cual comportamiento concreto o tipo de conductas o situaciones generales, susceptibles de ser lingüísticamente incardinadas bajo el vocablo emocionalizante en cuestión. Hasta con respecto a situaciones no conocidas aún por esa persona, cabe pensar que, como sucede con palabras que designan objetos de referencia corrientes (mesa, gato, el nombre de un equipo de fútbol, muerte, etc.), él les aplicará muy convencidamente alguna de dichas palabras («justo» o «injusto», etc.).

Solo que, por más determinados que los usos de esos términos puedan ser en la mente de cada sujeto, para él mismo, en cambio no se encuentran determinados para su funcionamiento inter-subjetivo en las prácticas de las comunicaciones lingüísticas concernientes a las diferencias de opinión reales sobre cuestiones políticas o morales o religiosas. La «vaciedad» consiste en que, si comparamos cómo el vocablo en cuestión es entendido respectivamente por variedad de locutores posibles, aun al ser aplicado a objetos de referencia bien determinados, resulta que hay muy sensibles desacuerdos en cuanto a si estos objetos considerados forman o no forman parte del círculo de «candidatos» positivos o negativos mentados por aquel.

En definitiva: fórmula «vacía» socioobjetivamente, sí, pero más o menos «llena» como indicación de conducta individual-subjetiva en la mente de cada quien, llegado el caso. Si a los auditores que ovacionaron ahí a Žižek se les hubiera preguntado por medidas concretas, seguramente cada uno hubiera sabido señalar tales o cuales para determinados asuntos específicos. Muy otra cosa es averiguar si estas medidas serían las mismas o muy similares, según respectivamente las convicciones personales de esos locutores; $y$ sobre todo, ideterminar cómo habrían de ser implementadas socio-económicamente! 


\section{6. ¿HACEN FALTA PRUEBAS? \\ (y sobre todo: ¿cómo obtenerlas?)}

Cualquiera fuere la contestación que al fin de cuentas se tenga por atinada para unos $u$ otros de los asuntos tocados (.. más bien habría que decir: «rozados») por Žižek, todas ellas implican, aunque sea tácitamente, alguna toma de posición sobre la siguiente cuestión metodológica cardinal: cuáles vías de conocimiento corresponde seguir para descubrir o verificar aquellas respuestas específicas que merezcan tenerse por acreditadas como verdaderas (segura o muy probable) al respecto. ¿Dónde, y sobre todo cómo, desentrañar las respuestas específicas verídicas con respecto al área respectivamente de distintos términos básicos indicados ahí? (p. ej., las recomendaciones a propósito de «elicidad»[supra $\S 3]$ ).

Ahora bien, $y$ salvo que ello sea enfocado como cuestión de simplemente barajar y comparar entre sí tales o cuales especulaciones, tomándolas como válidas por ellas mismas, cabe pensar que esos asuntos conciernen directamente, por lo menos en buena parte, a determinados conocimientos (no triviales) sobre uno o varios de los ítems siguientes: [1] des-velar ciertas regularidades socioempíricas decisivas para los resultados considerados, o en todo caso hacerlas recordar especialmente; [2] proceder a una descripción re-iluminada sobre ideales fundamentales históricamente dados o venir a plantearlos de cierta manera poco habitual, en tanto que juicios de valor categóricos (vale decir, ciertas valoraciones que se consideran in-discutibles ${ }^{54}$ ); [3] brindar sutiles observaciones críticas acerca de (1), con base en (2); [4] poner de relieve los pro y contra, con base en (1), de soluciones empíricas viables alternativas para solucionar lo señalado en (3), aquilatadas en tanto que juicios de valor instrumentales (racionalidad weberiana de medios empíricos ordenados a fines valorativos prefijados ${ }^{55}$ ).

Naturalmente, puede que determinado estudio en la materia señalada no escudriñe los cuatro renglones o se detenga mucho más

\footnotetext{
54 Supra: n. 36.

55 Supra: n. 36.
}

en uno(s) que en otros. Mas si se entiende que ello está destinado a ofrecer, como pareciera ser el presente caso, unas orientaciones prácticas para las conductas de los seres humanos, no se echa de ver cómo tal cosa se podría alcanzar sin tomar en cuenta decisivamente (aunque no fuera exclusivamente) al menos las respectivas condiciones reales ([1] y [4]).

En la medida en que lo señalado para cada uno de estos rubros no sea de reconocimiento obvio, o muy poco menos, se plantea la cuestión de fundamentar las afirmaciones respectivas. Salta a la vista, para quienquiera que tenga la información elemental sobre epistemología del razonamiento práctico, que las indicaciones principales para probar tales afirmaciones -i.e., acreditarlas racionalmente, o al menos respaldarlas mediante unas argumentaciones reconocibles como «razonables»- se conforman mediante requisitos metodológicos que no son iguales para todos esos cuatro rubros. Bien cabría preguntar, pues, si tales o cuales de las aseveraciones efectuadas en dicha ocasión se asientan en requisitos básicos de examinabilidad intersubjetiva (condiciones mínimas de distinción-precisión, posibilidades de falsabilidad empírica efectiva $y$ controles de coherencia, etc.). $\mathrm{O}$ si es que, en cambio, se sobreentiende que esas aseveraciones han de ser pura y simplemente aceptadas tal como fueron presentadas ahí, autosustentadas sobre la fe plena de quienes confían sin más en lo «eminente» que es la palabra de determinado locutor académico. $\mathrm{O}$ bien, puede haber a quienes les baste de por sî con abrazarse a los encantos de la sonoridad persuasivo-emocional propia que de antemano tienen las etiquetas invocadas.

$$
* * *
$$

Considerar distinciones como esas [1-4] que he señalado, $y$ abordar los respectivos controles de empiricidad, seguramente es tenido por cosa superflua para quienes disfrutan de abordajes como los de Žižek; así como sobreentienden que no hay por qué ni para qué someter tales aproximaciones a análisis de lenguaje [supra $§ 5 . \mathrm{a})$ ]. 
Es verdad que para muchísimas investigaciones sobre cuestiones sociales, si bien podrían caber preguntas similares a esas que he formulado, no se empieza por plantear tales interrogantes. No hace falta hacerlo cuando reinan acuerdos implícitos al respecto, como también semejantes acuerdos presiden nuestras comunicaciones lingüísticas habituales sobre infinidad de asuntos. Pues bien, ¿es tal el caso asimismo en cuanto a esos términos claves en torno de los cuales se consideró atinado discurrir de la manera como ello tuvo lugar en este debate?

Por más que esos ideales intelectualistas se invocan ahí como dogmas autoevidentes (cognitivismo axiológico ${ }^{56}$ ), tal vez no sea fútil preguntar en qué se asienta la eventual credibilidad de esas aseveraciones.

Pues bien, lo indagable al respecto no puede ser si dichos enunciados son verdaderos o falsos. No son ni lo uno ni lo otro ${ }^{57}$, ya que consisten primordialmente en ciertas recomendaciones o buenos deseos, o en todo caso significan juicios de valor categóricos. No son juicios de valor instrumentales, «testables» empíricamente, pues no vienen respaldados por referencia a posibles comprobaciones empíricas sobre eventuales relaciones efectivas de medios a fines ${ }^{58}$. Mas la distinción entre estas dos categorías claves de los encuadramientos axiológicos, la más elemental de todas para poder examinar racionalmente cualquier razonamiento valorativo, no asoma para nada (ni aun implícitamente) en los planteamientos de Žižek.

$$
* * *
$$

56 Cfr. Haba, 2010a: Sec. C.I (p. 51 y ss., «Cognotivismo axiológico»).

57 Téngase en cuenta, eso sí, que el término «verdad» se entiende aquí en su sentido normal, realista (no de maneras falaciosas, unas $u$ otras, destiladas por autores como Habermas, Foucault y los postmodernistas en general): cfr. Haba, 2015. (¡Nada que ver, desde luego, con la mistificadora etiqueta «posverdad»!).
Sin embargo, no por tratarse ahí de consejos o de valoraciones absolutas cabe concluir que, simplemente porque estos son unos enunciados de tal orden, corresponde rechazarlos ad portas. Las recomendaciones y los juicios de valor desempeñan funciones de orientación indispensables para desenvolvernos en nuestras vidas, no podemos vivir sin ser movidos por emociones. Mas la cuestión de fondo es, aquí: i) ¿tales afirmaciones, específicamente las formuladas ahí por Žižek, están en condiciones de servir de veras para suministrar orientaciones efectivas, nos aclaran cómo hallar decisiones de eficacia práctica ante cuestiones sociales reales controvertidas o a resolver nuestros problemas personales de «felicidad»? ii) O bien, aun si nada de eso revistiere utilidad práctica como directiva para discernir cursos específicos de acción: ¿será que ello nos suministra, eso sí, cierto conocimiento nuevo o muy poco divulgado sobre cómo funcionan unos entretelones sociales en que estamos inmersos, por más que sigamos siendo tan impotentes como antes para enmendarlos en todo o en parte? (paralelamente a como, mutatis mutandis, la astronomía proporciona conocimiento sobre explosiones en galaxias, sin que por saber esto alcancemos ni la más mínima posibilidad de influir en esos cursos de las cosas).

No veo cómo podría ser contestada afirmativamente, ya sea mediante información consabida o invocando ciertas pruebas nuevas, ni la una ni la otra de dichas dos preguntas. También al respecto es aplicable, mutatis mutandis, una observación como la siguiente:

«¿... quizá ofrecen [esas presentaciones discursivas] ... uniformidades empíricas recién descubiertas o correlaciones de variables empíricas causal-probables, o una serie de hechos empíricos [sociales] de naturaleza muy importante o una notable interpretación de datos empíricos? ¡Ay! No ofrecen conocimiento alguno de esa clase, por la sencilla razón de que casi no tienen material empírico [diferenciado con cierto mínimo de precisión]. Intentando ser sometidas a prueba empíricamente, las teorías se mueven en 
un reino metaempírico de abstracciones que raramente tocan la región empírica prosaica. Desde el punto de vista de la exploración empírica y de hallar hechos, no añaden nada nuevo a nuestro conocimiento de los hechos y relaciones psicosociales» 59 .

Mas tal puntualización podría ser objeto de dos reparos básicos. Paso a examinarlos.

a) Es verdad que no es lo mismo esos «datos empíricos» que las valoraciones de las cuales podamos hacerlos objeto $y$ que las propuestas para introducir ciertas modificaciones sobre unos aspectos de aquellos. Podría decirse, entonces, que la «sal» de puntualizaciones como las de Žižek reside justamente en trascender el mero conocimiento de esos datos en-sí, pues no es sino mediante unas selecciones valorativas de tales «datos» cómo resulta posible delinear acciones conscientes de personas, con vistas a obtener la realización de unas u otras finalidades propuestas. Estas últimas se hacen presentes en conciencias de seres humanos, y para llevarlas a cabo necesitan ser implementadas por personas que las conozcan; ello no viene dado por un desenvolvimiento automático de «material empírico» librado a su propia suerte. -Llamémosle a estas observaciones: posible objeción (a) contra mi crítica.

b) Por lo demás, ciertamente no es igual dar cuenta sobre cómo se producen unas regularidades empíricas en tales o cuales órdenes de comportamientos humanos colectivos - suele llamársele: «hechos» sociales- que señalar unas aspiraciones al respecto — suele llamársele: «ideales» o «valores»- anidadas en la cabeza de muchas o pocas personas. Esos ideales pueden o no coincidir, en grados mayores o menores, con esos hechos. Pero resulta que, aun si no coinciden, esto no significa que los ideales en cuestión dejen de ser tales: "están» ahí mientras haya personas que creen en ellos. Y es verdad que ese modo de "estar» no es refutable mediante comprobaciones empíricas sobre cualesquiera desfases, totales o parciales, entre lo uno y lo otro: ideales/realidades. —Llamémosle a estas observaciones: posible objeción (b) contra mi crítica.

Pido disculpas por reiterar aquí señalamientos tan elementales: (a) + (b). Solo que, si bien dicen verdad, he aquí que más bien eso mismo suele no ser diferenciado debidamente cuando, como es no poco habitual en la filosofía social, se hace abstracción de que no menos cierto es también que:

«For no one can, with intelligence, discuss what ought to be, unless he is moderately familiar with things as they are» 60 .

No objeto que Žižek, o quien fuere, se afane por destacar todos los «ought» que le parezcan interesantes. Mas cuando ello se hace de la manera como procede a presentarlo él, queda por averiguar ni más ni menos que lo siguiente: antes que nada, ¿cómo distinguir netamente las «things» a que se refieren esos buenos deseos? Por lo demás, ¿cómo saber, a ciencia cierta o en todo caso con buenos grados de plausibilidad verificables como tales, cuáles son concretamente y cómo es dable poner en práctica las conductas-«ought» propugnadas? (esto es: cómo identificar los datos de descripción diferenciales que permitan distinguir intersubjetivamente esos comportamientos frente a cualquier otro comportamiento posible). En una palabra: ¿qué contenidos específicos tendrían, y cómo aplicarlos, las disposiciones estatales específicas (leyes u otras) adecuadas para implementar la realización efectiva de cuanto Žižek entienda — iél sabrá qué es! — por «las verdades» ${ }^{61}$ ?

\footnotetext{
$60 \quad$ Frank, 1942, p. 315 (curs. E.P.H.).

61 Supra: en la tanda de citas que vienen poco después de la correspondiente a la n. 26 .
} 
Está no poco lejos de quedar claro cómo identificar esos contenidos mismos, aun si concedemos hacer a un lado preocuparnos por indagar si son o no son realizables. Semejantes buenos deseos académicos no brindan, ni aun en su nivel meramente semántico, cierta precisión como tienen ciertos otros pliegos de mandatos axiológicos categóricos, por más que tampoco estos suelan ser muy acatados en la práctica. Si nos fijamos en los Diez Mandamientos, para la gran mayoría de los casos no ofrece mayor duda (supuesto que se acepte tomar dichos enunciados al pie de la letra) advertir, por quienes deseen fijarse en ello, si unas $\mathrm{u}$ otras conductas corrientes cumplen o incumplen con lo indicado en tales o cuales preceptos de ese catálogo, o si ellas sean indiferentes al respecto. Difícilmente alguien dudará qué quiere decir ahí: «Dios» (se entiende que es El señalado en la Biblia, nadie confundirá Su Palabra con las canciones de Julio Iglesias o con los tuits de Donald Trump y ni aun con los discursos del propio Žižek), «matar» (se entiende que la referencia es a seres humanos), «fiestas» (se entiende que son las indicadas por las autoridades religiosas reconocidas como tales), «robar», «mentir»y demás. [Desde luego, cabe invocar razones que se estimen justificadas para «matar», «mentir», etc.; pero no es que unos entiendan por conducta-«matar» lo que otros entienden como conducta-«santificar», etc.]

En cambio, ¿será que términos como «libertad» «dignidad», «causa significante», «deber», «autenticidad», etc., cada uno de ellos señala respectivamente determinados comportamientos o valoraciones que son más o menos los mismos (respectivamente para cada una de dichas palabras) si esas expresiones las emplean, por. ejemplo, tanto sostenedores de la ideología de «género» hegemónica como sostenedores de los derechos individuales en sus alcances humanistas clásicos? (más aún, hasta en el propio seno de cada una estas dos grandes orientaciones globales no faltan múltiples discrepancias al respecto).

Pues sí, «recetas» como las obtenidas mediante esos entia doctrinarios de Žižek, son ciertamente muchísimo menos específicas que buena parte de los mandamientos canónicos de cualquiera de las religiones tradicionales o de las instrucciones ofrecidas por los utopistas clásicos o varias del propio Marx. [Tal vez, para cada caso o tipo general específico de situaciones sociales típicas sería cuestión de solicitar su dictamen de indicaciones prácticas concretas al propio Sr. Žižek. O acaso podrían ser consultadas, a falta de estar él mismo disponible para ello, ciertas otras personas con «figura de maestro» ${ }^{6}$ ].

Tal manera de abordar las cuestiones sociales difiere muy poco en lo sustancial (aparte de acudir a engalanarlo con unas pedanterías discursivas para consumos especialmente académicos) de los expedientes de distraccionismo típicos en la propaganda de los candidatos a puestos políticos de elección popular: «digo qué, pero no digo cómo...». Solo que, por añadidura, en enfoques como los Žižek: jaun ese «qué» mismo es de lo más indeterminado!

[C]

\section{RESULTADO}

\section{7. ¿DE QUÉ «CONOCIMIENTOS» SE TRATA? (los «esperantos» en cuestión)}

Al lector no le agrada comprender, le gusta atascarse, encenagarse, le encanta ser castigado. De ahí el prestigio de los autores confusos, de ahí la perennidad del fárrago (fatras) ${ }^{63}$.

Cioran (2006, p. 9).

La notoriedad alcanzada por Žižek en ciertos círculos de universitarios se debe, curiosamente, a que él pasa por ser ni más ni menos que un «iconoclasta» como filósofo social de «izquierda». Ello responde a la circunstancia de proclamarse marxista, mas con la peculiaridad de no respaldar el hegemónico marxismo «cultural» que es impuesto en las universidades y la «neoinquisición» consiguiente (implantación del «pensamiento único», el cual puede ser reforzado inclusive mediante la introducción ahora de legislación-bozal — delitos de «odio», leyes de «memoria histórica», etc.— que ponga

\footnotetext{
62 Cfr. el pasaje indicado en la n. 40 (supra).

63 Trad. aquí: E.P.H.
} 
en manos de las autoridades estatales instrumentos coercitivos cada vez más ilimitados de censura y hasta de castigo penal, para acallar opiniones incómodas) [cfr. Kaiser, 2020].

Žižek no congenia con ese «marxismo»: no homologa lo «políticamente correcto», no adhiere al adoctrinamiento en la ideología de «género», etcétera. Así ofrece una alternativa ideológica atractiva para bienintencionados intelectuales que, aunque se sienten defraudados por la realidad de los Estados llamados «socialistas» y rechazan dicha neoinquisición, siguen experimentando la necesidad subjetiva de no ceder el timbre de honor de poder contemplarse como "progresistas». Escapatorias por la tangente como los divertimentos filosóficos de Žižek halagan la buena conciencia de quienes sienten la necesidad de seguir aferrados, pase lo que pase, al artículo de fe básico mediante el cual filtran todo conocimiento acerca de lo social: mantener su pensamiento político cautivo en la pernoctación ideológica, no menos para los días que para las noches, de celebrar unos universos discursivos de ensoñaciones futuristas. Ergo, inmunes a falsación empírica. Postulaciones donde el «progreso» de las colectividades humanas se alcanzaría, iwishful thinking manda!, mediante el reemplazo de la «explotación» capitalista por unas organizaciones estatales especialmente colectivistas compuestas por ciudadanos ideales [véase infra Sec. D].

Las observaciones de Žižek afincan en tal plano de examen, «idealismo especulativo» ${ }^{64}$. $\mathrm{Su}$ «iconoclastia» consiste en concentrar el pensamiento político académico en objetar unos iconos «marxistas» (los malos: socialismo real) por no concordar con otros iconos «marxistas» (los buenos: socialismo ideal). Por eso mismo no es de extrañar que, como ha quedado en evidencia una y otra vez a lo largo del presente comentario, sus recomendaciones no «aterrizan» en constataciones empíricodescriptivas sobre regularidades para comportamientos sociales o dinamismos económicos subyacentes (trivialidades aparte). Las decisivas interrogantes de know-how ${ }^{65}$ —dinamismos económicos no-voluntaristas, impulsos sociales efectivos, en general conocimientos científicos elementales sobre psicología social, etc.- no sacan la cabeza ni por asomo a lo largo de esas fervorosas iluminaciones doctrinarias ${ }^{66}$.

Ahora bien, ¿estos apartar-la-vista-de significan que tal exposición no pone sobre la mesa saber alguno? (fuera de llamar la atención hacia algunas citas de autores agudos y reiterar unas informaciones muy conocidas sobre algunos aspectos de las sociedades actuales, aparte de mencionar alguna información científica elemental bastante difundida). No es del todo así. Esa exposición no podría haber sido confeccionada de tal manera sin desplegar también ciertos «conocimientos» — principalmente en cuanto a presentación de íconos doctrinariosque no son habituales, ni adentro ni afuera de las ciencias normales.

¿Qué orden de «conocimientos» especiales son estos últimos? Permítaseme recurrir inicialmente a un ejemplo imaginario burdo, con el propósito de dirigir la atención de un modo gráfico (me parece) hacia dónde reside tal «especialidad».

Supongamos que propongo formular en esperanto dos afirmaciones, independientes entre sí: a) «en algún lado existe determinada cosa esferoide»; b) «son más de cien los perros domésticos distribuidos entre hogares de

65 Téngase en cuenta señaladamente la distinción indicada supra: n. 36 .

66 Véase, p. ej., los componentes de la receta que Žižek ha logrado descubrir como solución para las migraciones masivas [1:09:00]: «... alguna [ii !!] manera de cambiar la situación ... y somos cómplices [¿quiénes? y ¿cómo?, ¿todos por igual?] en esto [irotundas aclamaciones en el auditorio presente!] ... la verdadera utopía es que podamos sobrevivir sin tal (¿cuál?, ¿cómo?) cambio...». ¡Nada acerca de las concretas complicaciones reales que conforman esa problemática en los hechos!: antinomias culturales, imposibilidades económicas, etc. [para las aclaraciones básicas sobre ello, cfr. Kaiser, 5 de junio de 2017; véase además Haba, 3 de mayo de 2019, § 9 (p. 33 y ss., sobre «"derechos humanos" y multiculturalismo»)]. - Más ejemplos de remedios sociales a la Žižek, supra: cfr. el grupo de citas ubicado a la altura de las nn. 17 a $21+$ el de $\S 3 . \beta)$ in fine. 
San José». Desde luego, nadie puede efectuar estas formulaciones en esperanto sin tener conocimientos de ese idioma, ni a falta de esto último entenderlas debidamente si le son presentadas así. Semejante conocimiento, el del esperanto, constituye un saber especializado. Para adquirirlo se necesita efectuar estudios que pocas personas poseen; no cualquiera sabe lo necesario para poder apreciar si esas traducciones son correctas de acuerdo con tales patrones lingüísticos.

Pues bien, sean o no sean correctas lingüísticamente —isegún esos patrones! — las versiones en esperanto de las susodichas afirmaciones, es harina de otro costal averiguar respectivamente: a) ¿cuál es (en qué consiste, dónde está) la «cosa» mentada en esta aseveración?; b) ¿de veras hay tantos perros ahí?

Para (a): no menos si ello se dice en esperanto que cuando se dice en español, la averiguación de eso es prácticamente imposible, pues no se nos ha señalado en qué punto circunscrito de espacio-tiempo hemos de buscar esta «cosa» determinada; e incluso si nos ubicasen inconfundiblemente ese punto, y si bien el reconocimiento de que unos objetos son esferoides es dable obtenerlo mediante la percepción normal intersubjetiva proporcionada por los órganos de la vista en los seres humanos comunes, siempre quedaría por saber de cuál específico objeto esferoide (la «cosa» en cuestión) se trata, si hay varios que muestran tal apariencia ahí.

Para (b), en cambio, es obvio que no hay mayor dificultad en saber si eso es verdad: basta con que alguien se tome el tiempo de buscar un número suficiente de perros en casas josefinas, valiéndose para reconocerlos como tales (perros, no gatos) de la vista normal.

[Acotación.- Es verdad que ni aun el enunciado (a) viene a ser ciento por ciento in-determinado, pues esferoide se diferencia fácilmente de rectangular, poligonal, etc. Mas la circunstancia de que una o más notas de un concepto no sean vacuas en sí mismas, no obsta a que en tanto lo sean otras, es en esta última medida -que puede ser amplísima - cómo resulta tan in-determinado ese concepto en su conjunto: entonces no es dable aprehender intersubjetivamente a qué, dónde, cuándo y sobre todo cómo ha de ser aplicada la idea en cuestión. Es el caso del enunciado (a)].

En una palabra: mientras que sobre (a) no disponemos de ningún instrumento de conocimiento confiable para discernir dónde acaso esté presente empíricamente (alcances extensionales) aquello nombrado ahí, sea ello lo que fuere; en cambio, no hay por qué tener duda alguna sobre si existe o no existe lo nombrado en (b), siempre y cuando estemos dispuestos a tomarnos el trabajo de verificarlo empíricamente. Pero he aquí que el conocimiento posible sobre la eventual existencia efectiva (o la ausencia de ella) de la «cosa»-(a) o el de la «cosa»-(b), ini lo uno ni lo otro dependen de que se posea también aquel otro tipo de conocimiento!, jeste que consiste específicamente en entender el esperanto! Por más experto que uno sea en esperanto, tal experticia no hace ni más ni menos confiables sus afirmaciones sobre (a) o sobre (b).

El «esperanto» a que recurre Žižek es señaladamente esa terminología de sus planteamientos. La "gracia» ahí consiste en asociar esas etiquetas con ciertas informaciones elementales y señalar unas posibles relaciones semánticas de ello con algunas perspicaces sentencias de pensadores célebres. Mas lo que está en discusión no es la veracidad de esas informaciones en sí ni la agudeza de dichas sentencias, sino qué pueda añadir este «esperanto» por sí a los saberes mismos sobre la materia. En verdad, les «añade» apenas la peculiaridad de que tales informaciones o esas sentencias son entonces recogidas en el seno de esas formulaciones grandilocuentes. Asociación aprovechada, a su vez, para hacer pasar los caballos de Troya del «idealismo especulativo» que ahí se dio a la tarea de venir a recomendar Žižek.

Estas recomendaciones están compaginadas principalmente mediante un repertorio de ditirambos-vs.-anatemas que se asienta sobre términos-base cuyos ámbitos semánticos son confortablemente «gelatinosos» [supra 5.ß)]. Y desde luego no hace falta, para discurrir así, preocuparse por confrontar eso con condiciones empíricas sociales efectivas. Al contrario, lo que importa sobre todo, ahí, 
es justamente que «este debate trascienda cuestiones puramente económicas ... en el marco de la felicidad, del ser humano floreciendo por sí mismo» ${ }^{67}$. Entonces basta y sobra con constatar que tales pregones calzan con la «gramática» (Wittgenstein) propia de ciertos juegos de lenguaje académicos, el «esperanto» invocado ${ }^{68}$.

\section{8. ¿HUBO «DEBATE? \\ (un «debate» a la medida de...: la gracia filosófica del «vorbeireden»)}

\section{La ilusión es el primero de todos los placeres} Voltaire (2019)

A esta altura estamos en condiciones de preguntarnos: ¿hubo verdaderamente «debate» ahí? ¿Lo expuesto por Peterson fue contradicho, en todo o en parte, por las invocaciones de Žižek? Para que una afirmación (A), ya sea de señalamiento descriptivo-factual (sobre existencia de cierto evento particular o sobre regularidades empíricas determinadas) o de calificación valorativa (sobre cierto comportamiento humano particular o sobre una generalidad de ellos), esté en contradicción con otra afirmación (B), en todo o en parte, necesita darse lo siguiente: la aseveración A significa no-B, la aseveración B significa no-A.

Qué signifique cada una de las afirmaciones depende de cuáles creencias específicas se imputen respectivamente a estas emisiones verbales, en las mentes de los participantes en esa comunicación (aun con independencia de si son o no son acertadas cualquiera de las convicciones en que consisten dichas creencias: p. ej., hay contradicción entre decir que el personaje $\mathrm{X}$ es una sirena $\mathrm{y}$ decir que es un centauro). Mas la contradicción existe solamente si A y B son dos referentes mentales claramente reconocibles, en su diferencia, por parte cada miembro (o, en todo caso, la gran mayoría entre estos) del conjunto de hablantes-auditores que se

$67 \quad$ Palabras del presentador [06:15].

68 Al fin de cuentas, las disputas al respecto vienen a ser algo así, mutatis mutandis, como las discusiones en la doctrina del derecho sobre cuál sea la interpretación verdadera para unas «novelas de conceptos» de la dogmática jurídica [cfr. Haba, 2013]. refieran a ese asunto, en una ocasión determinada o en general cuando son mencionadas estas «cosas» específicas. Ahora bien, aplicado a nuestro asunto: ¿cuáles fueron ahí tales A y B? (¿̨o además también C, D, E, etc.?). Por mi parte, no he conseguido detectarlo.

Más allá de qué tenga o no tenga que ver con «felicidad», «marxismo»y «capitalismo» lo dicho por Žižek, no veo cuáles de sus afirmaciones, tanto si son como si no son ciertas, resulten incompatibles con tales o cuales afirmaciones de Peterson, sean o no sean empíricamente verdaderas estas últimas. Al menos en cuanto a sus respectivas exposiciones iniciales, la relación entre ambas se presenta como si uno hubiera hablado sobre cultivo de amapolas, el otro habló sobre nidos de palomas... (si bien pudiera ser que, una de esas, el árbol donde anidan esas palomas estuviera cerca de donde crecen esas amapolas). Vale decir que la veracidad o plausibilidad, o las carencias de ello, tanto de cualquiera de las afirmaciones del uno como de cualquiera de las del otro, ello no depende, al menos de manera expresa, ni las primeras de las segundas ni las segundas de las primeras. No hay discusión propiamente dicha entre lo sostenido en una vereda frente a lo sostenido en la de enfrente ${ }^{69}$.

Si se consideran las puntualizaciones señaladas en la sección A [esp. § 4.ß)], hay que hilar bastante fino para hallar contradicciones propiamente dichas entre los dos protagonistas de esa conversación. En efecto: ¿lo indicado por Peterson contradice unas aseveraciones de descripción empírico-social que forman parte

$69 \quad$ Podría ser que las contradicciones estuvieran implícitas ahí, esto es: que si se sacan a luz ciertas implicaciones (apenas tácitas) de «cosas» señaladas desde la vereda A y ciertas implicaciones para «cosas» señaladas desde la vereda B, entonces saltan a la vista contradicciones, sea entre esas implicaciones mismas o entre alguna(s) de ellas $y$ la tesis manifiesta A o B. Si A implica $j$ y B implica $k$, siendo $k=$ no-j, entonces resulta que, aunque ni en A mismo ni en B mismo se mencionen expresamente $j$ o $k$, las afirmaciones A y B son incompatibles, total o parcialmente: si A es verdad, B es falso, o viceversa, al menos en cuanto a ciertas partes de esas afirmaciones (o podrían ser falsos ambos, tanto A como B, total o parcialmente). 
(algunas hay ahí) de la homilía ético-política presentada por Žižek?; ¿̇ este último señaló que faltan a la verdad aquellas aseveraciones en sí mismas?; o bien, ¿las edificantes recomendaciones para encaminar la vida propia de cada persona con que ello es vinculado por Žižek son indeseables según Peterson? Ninguna de estas preguntas — son las cruciales, a mi juicio- es dable contestarla afirmativamente, si se examina cuanto ellos dos señalaron en esa ocasión.

¿Entonces quiere decir que, después de todo, ambos vinieron a decir más o menos lo mismo, solo que cada uno verbalizándolo a su propia manera? Hay una palabra del idioma alemán que literalmente expresa muy gráficamente cómo fue de veras la relación-entre-discursos presentada ahí. Bien mirado, se trató sustancialmente de un vorbeireden por cuanto hace a señalar las cuestiones empíricodescriptivas claves Esto es: las afirmaciones $\left(\right.$ reden $\left._{2}\right)$ de Žižek se contentaron con pura $y$ simplemente pasar-de-costado-afuera (vorbei) frente a las afirmaciones $\left(\right.$ reden $_{1}$ ) de referencia empírico-social presentadas en la exposición inicial de Peterson ${ }^{70}$.

¿Puede alguien señalar la existencia de qué hechos - unas regularidades socio-conductuales o ciertos rasgos psicológicos- fue controvertida ahí? ¿Acaso las constataciones sobre realidades sociales del capitalismo indicadas por Peterson (en la exposición inicial) fueron propiamente negadas por Žižek? Y recuérdese que después, en la segunda mitad de esa actividad, ni aun el propio Peterson volvió sobre eso mismo. Si bien los dos vinieron a «encontrarse» —ipara coincidir! - en sus intercambios de unas poemáticas terminologías ético-teológicas, esas sobre las cuales concentraron su conversación en la segunda parte del evento ${ }^{71}$, quedaron entonces fuera de foco (vorbei) justamente aquellas anotaciones básicas de Peterson ${ }^{72}$.

70 Por cuanto hace a esta presentación, en sí misma, no hay por qué vincularla a cuanto más adelante Peterson pasó a entonar, modo «segunda voz», en armonía con aproximaciones como la del propio Žižek [véase el pasaje indicado supra: n. 38].

71

Supra, $\S 4 . \beta): \mathrm{f}, \mathrm{g}_{2}, \mathrm{~g}_{3}$.

72
$* * *$

No obstante, empeñémonos aún en tratar de localizar alguna verdadera oposición entre los planteamientos presentados ahí, a pesar del vorbeireden básico y las subsiguientes armonías belletrísticas que obtuvieron el asentimiento de ambos expositores. Hay dos puntos que parecieran marcar alguna contradicción entre la consejería política positiva que ofrece Žižek ${ }^{73}$ en comparación con lo recomendado por Peterson ${ }^{74}$. Señala el primero:

1) «...el problema de los océanos, la única forma para mí es una acción cooperativa internacional y demás. Uno no puede dejárselo simplemente al mercado» [1:30:00].

2) «¿Por qué pones tanto énfasis a eso de que tenemos que comenzar por un cambio personal? ... [vale decir:] Primero pon tu casa en orden, después... ¿Qué pasa si al intentar ordenar tu casa terminas descubriendo que está desordenada precisamente por el modo en que la sociedad está arruinada? Lo que no significa que me olvido de mi casa, pero puedes hacer ambas cosas al mismo tiempo» [2:05:00]. No es venir a contentarse con simplemente la satisfacción personal de cumplir con unos pequeños «deberes» personales («personalización falsa», «forma falsa de desentenderse»): p. ej., en cuanto a la ecología, no basta con cumplir uno mismo con el deber de reciclar [2:07:15].

En cuanto a 1), por supuesto que a nadie con dos dedos de frente se le pasará por las mientes negar que hay ciertas cuestiones importantísimas de la convivencia humana actual que se resuelven en gran medida, mal o bien, mediante unos órdenes de interrelaciones convenidas (o al menos consentidas) internacionalmente entre las autoridades de varios Estados. Es verdad que, en su elogio del mercado capitalista como la ordenación social más

\footnotetext{
$73 \quad$ Supra, $\S 4 . \beta): \mathrm{g}_{2}$.

74 Supra, 4.(3): $\mathrm{g}_{1}$.
} 
favorable para la producción y la distribución de bienes, Peterson no indicó que existe el Derecho Internacional, el cual desde luego no se podría limitar a simplemente asegurar una circulación bastante libre y segura de productos entre distintos Estados. ¿Para qué Peterson hubiera necesitado venir ahí a reiterar cosa tan palmaria? Por lo demás, no se ve en qué esta obviedad estaría en contradicción con señalamiento alguno de los efectuados expresamente por él en su exposición sobre historia del mercado capitalista. (Está de sobra, me parece, detenerse más en esta trivialidad).

El punto 2) viene no poco «enredado». Recuérdese que cuando Žižek efectúa ahí esas observaciones sobre «hacer ambas cosas», a esta altura Peterson ha dejado completamente atrás las sobrias anotaciones descriptivoempíricas delineadas en su intervención inicial. Si bien no las rectifica propiamente, se pliega de cuerpo entero a des-concentrar la atención por cuanto hace a fijarse en aquellas mismas, pasa a ocuparse de otras «cosas». Ya reubicado en discurrir mediante unos juegos de lenguaje cuyas "gramáticas» son no poco análogas a modalidades discursivas como aquellas en que difumina las cuestiones prácticas concretas el propio Žižek, la respuesta al respecto de Peterson consiste en una cantinflada (iperdóneseme la franqueza del graficismo!) que él explaya por varios minutos ${ }^{75}$.

75 Se halla ubicado aproximadamente entre 2:11.20 [a partir de «...la situación en la cruz...»] y 2.16:40 [«... está asociado a esta moralización superficial»]. Si bien se mira, no estamos muy lejos ahí de encontrarnos ante algo así como ese tipo de bruma intelectual que Vaz Ferreira llamó las «falacias verbo-ideológicas» [1963, cap. homónimo]. Lo cierto es que Peterson a veces (no digo que sea así en la mayor parte de sus exposiciones) tiende a escaparse por la tangente, sobre todo cuando le son planteadas cuestiones filosóficas demasiado complejas para ser abordadas con base simplemente en el «sano sentido común» o en su experticia profesional sobre dificultades psicológicas individuales: p. ej., véase el «enredo» en que se dispersa por las ramas para (no-)responder en concreto a una pregunta tan precisa como la que llegó a serle planteada sobre un punto específico de la problemática acerca del aborto [ello en su intervención de 15 de junio de 2018]. Véase también infra: n. 80.
De ese simpático menjunje entre invocaciones que respectivamente son ya sea de carácter teológico, ético, psicológico-individual, y sobre correspondencias sociales al respecto, entresaco unos pasajes como bastante representativos de las directivas centrales encomiadas ahí por Peterson:

«Y yo creo que el principal mensaje psicológico del corpus bíblico es... [cómo hacer para] vivir el tipo de vida que establecerá tu casa en orden y la casa de todos en orden al mismo tiempo» [2:12:45]. «... creo que la mejor apuesta para la mayoría de la gente es resolver los problemas que les afectan su propia vida, los problemas éticos que les afectan ... para que luego puedan ser capaces de lidiar con problemas sin caer presa de algunos de los errores que caracterizan, digamos, a los más superoptimistas e intelectualmente arrogantes ideólogos... si tomas un problema individual suficientemente en serio, resolverás simultáneamente un problema social ... [p. ej.:] si acabas estableciendo una relación [de familia] con una mujer ... [es así cómo] te enfrentas [ahí] de forma inmediata con todos los problemas sociológicos en un microcosmos en esa relación ... [así es cómo, cuando uno logra darse cuenta sobre cuál] es realmente el problema [personal suyo] y obtener el diagnóstico correcto, [entonces] te has movido en una pequeña medida hacia adelante en lo que podría constituir la preocupación más amplia» [2:13:15]. —Véase también supra, § 4.(): b), e), f).

Comparando esta transcripción con la segunda [2)] de Žižek recogida más atrás [a la altura de la n. 74], se diría que tal vez la diferencia eje residiría en que: según el primero se debería «comenzar por un cambio personal», mientras que para el segundo corresponde «ordenar ... la sociedad arruinada ... al mismo tiempo». A decir verdad, de dicha cantinflada de Peterson tampoco surge neta tal diferencia: «... si tomas un problema individual suficientemente en serio, resolverás simultáneamente un 
problema social», entonces «te has movido en una pequeña medida hacia adelante en lo que podría constituir la preocupación más amplia». Por lo demás, recuérdese que al fin de cuentas el propio Žižek se declara sin ambages como antes bien «pesimista» ${ }^{76}$ en cuanto a poder lograr tal «ordenamiento».

Aun si, sutilizando, se consiguiera localizar alguna diferencia relevante (i.e., más allá de sus respectivas verbalizaciones específicas) entre ambas consejerías, no menos cierto es que tanto la una como la otra comparten la básica impronta discursiva de efectuar sus planteamientos mediante conceptuaciones que difícilmente podrían ser de carácter todavía más ultraabstracto general-generalísimas: «orden» en la «casa», «modo» de «la [iunicidad!] sociedad», «hacer ambas cosas», «problema individual»y «problema social», «movido ... hacia adelante», etc. - ¡levante la mano quien esté en contra de poder alcanzar eso!- .

En efecto, ambos concordaron en que lo principal es asunto tanto «individual» como «social». Solo que, a diferencia de mucho de lo apuntado en la primera intervención de Peterson, unas modalidades discursivas como estas otras son aptas para conjurar - en el despliegue interno de ciertos universos lingüísticos propios desempeñados en determinados sectores académicos especializados en ello- las evasiones hacia cualesquiera disposiciones sociales imaginarias, al gusto de consumidores de tales tipos de literatura. Sea o no sea que al fin de cuentas los «debatientes» hayan estado bastante de acuerdo en cuanto a unos $q u e ́$-sociales ideales por alcanzar pregonados ahí, y entiéndase como fuere (idecida el lector!) cuáles serían los contenidos prácticos efectivos en que supuestamente consistirían esos qué mismos, lo cierto es que ni Žižek ni Peterson condescienden a ofrecernos indicación alguna específica sobre cómo obtener que esas maravillas discursivas pasen de veras a hacerse «carne» en los empeños reales de la generalidad de los seres de carne y hueso (;Sabios aparte!) que componen los conglomerados humanos terrenales.

76 Supra, § 4.ß): $\mathrm{g}_{3}$.
Desde luego que para los efectos de disfrutar en debatir dentro de dichos universos discursivos, no puede sino quedar muy fuera de lugar indagar si existen óbices al respecto que corresponden a órdenes laicos de conocimiento científico sobre lo social: análisis lingüísticos realistas sobre discursos de cualquier ideología política, sociología empírica, politología empírica, economía empírico-realista, u otros saberes extradogmáticos no menos pedestres.

Si bien se mira, no menos estas disciplinas que mis comentarios aquí al respecto vienen a ser, después de todo, algo así como un «vorbeireden» frente a las precomprensiones básicas de Žižek (significados Verdaderos, esencialismo, fórmulas vacías, prescindencia de la racionalidad axiológica instrumental, etc.). Y muy probablemente estoy incurriendo asimismo en meros «vorbeireden» frente a los numerosos colegas que se felicitaron por el «nivel» teorético difundido mediante dicho evento.

$$
* * *
$$

En definitiva: salvo el desacuerdo en materia histórico-doctrinaria sobre principalmente qué inferir de unos textos de Marx [supra $\S 4$. (3.c)]), no se echan de ver oposiciones propiamente dichas entre lo señalado por ambos expositores allíi7.

Después de todo, lo cierto es que la diferencia más sustantiva entre lo planteado respectivamente por cada uno de ellos reside en lo siguiente: Žižek se ubica de pleno dentro de la rama wishful thinkers para la teorización académica sobre lo social ${ }^{78}$; Peterson es mucho más recatado al respecto, prefiere indicar unas «recetas» de la vida espiritualmente «sabia», para que cada quien que acepte seguirlas consiga «solucionar» justamente así sus intríngulis personales.

$77 \quad$ Hasta comentaristas que no salieron para nada complacidos (son los menos: supra n. 3) de cómo las cosas fueron plantearon allí, aun estos enfocaron su crítica en planos de cotejo con respecto principalmente a unas cuestiones de exégesis sobre literatura doctrinaria [así, p. ej.: Studebaker, 22 de abril de 2019].

Cfr. Haba, 2010b. 


\section{EXCURSO: ¿QUIÉN «GANÓ» ESTE (PSEUDO) DEBATE?}

Esa pregunta resulta más bien desorientadora. Aun suponiendo que ahí se hubieran elucidado cuestiones de verdadero-o-falso ${ }^{79}$, es obvio que propiamente esto no es lo mismo que preguntar sobre las cantidades de espectadores que respectivamente vinieron a quedar entusiasmados por cuanto sostuvo ahí cada expositor. Sin embargo, ya con toda independencia de la cuestión sustantiva verdadero-o-falso, interrogar sobre el «gane» se puede abordar descriptivamente como una investigación de orden socioempírico, esto es, en cuanto a detectar cuál fue la eficacia retórica de dichas exposiciones sobre mentes del auditorio. En tal sentido, bien puede decirse que resultó «ganador» el contendor que haya logrado impresionar como mejor «conocedor» ante ese auditorio. Vale decir que, para encontrar la respuesta a ello, el objeto cardinal de examen es fijarse en la composición del auditorio. Lo conforman: (i) quienes asistieron personalmente a esa actividad, (ii) quienes toman conocimiento de ella después por internet.

En cuanto a (i), tengo la impresión de que ahí Žižek, visto lo bullangeras que en la audiencia fueron las exclamaciones de adhesión sobre todo hacia especialmente algunas entre sus vaguedades retóricas, en general consiguió despertar mucha mayor «impresión» ante este auditorio, en virtud también de los enfáticos modos de exaltación oratoria emocional con que él mismo entonó sus intervenciones más aparentemente polémicas. Por su parte Peterson, luego de la intervención inicial, lució relegado a la defensiva, «opaco»; se le vio empeñado en ver cómo conseguir justificarse ante los ojos del propio Žižek, mediante unas observaciones destinadas a tratar de ponerse a tono con las impresionantes maravillas «filosóficas» (teologales y demás) de que se iba enterando ahora por boca de este último.

Las fundamentales lagunas de Peterson en materia filosófica, y sobre todo su patente orfandad - no menor que la del propio

79 Mas téngase presente lo advertido supra: a la altura de la n. 57.
Žižek- en cuanto a atender precauciones elementales de epistemología analítico-realista (análisis del lenguaje ordinario, teoría de la argumentación, retórica de la discursividad política, etc.) para abordar la materia considerada, hizo que aquel resultase presa fácil de unos juegos de lenguaje académicos difuminadores como esos de su contendor ${ }^{80}$.

80 Acotación. - Habiéndome detenido a ver unos cuantos vídeos de Peterson, eme dan toda la impresión de que para él es territorio insospechado - si bien, desde luego, no lo puedo asegurar- unos saberes elementales en teoría de las ciencias sociales (p. ej., fundamentales puntualizaciones metodológicas de Weber, conocimientos tipo Berger/Luckmann y Bourdieu/Chamboredon/ Passeron, etc.) y en general nociones básicas de epistemología de la Razón práctica (teoría de la argumentación, langage ordinary philosophie y demás); eso aun con independencia de ser poco versado en filosofía profesoral, como aprovechó para echarle en cara Žižek. De ahí que no pocas veces, a pesar de ser él (me parece) un académico honesto intelectualmente y muy sano éticamente en sus posiciones políticas (es notoria su señalada valentía en desafiar lo «políticamente correcto»), por lo demás persona muy inteligente y que con frecuencia efectúa observaciones agudas, empero resulta que, al abordar cuestiones que desbordan por mucho los límites de su propia especialidad profesional —psicología clínica: consejos para la «espiritualidad» individual-, entonces sus planteamientos se precipitan en unos «enredos» de discursividades [supra nn. 24 y 25]. Tal vez podría prevenirse de ello si esos temas no los abordara tan espontáneamente; esto es, si se preocupase por tratar de averiguar antes qué investigaciones fundamentales existen sobre tales asuntos, al menos algunas de las bastante difundidas al respecto. [P. ej.: en elucidaciones de Peterson (15 de junio de 2018) sobre religión, las desarrolla como si nunca hubieran sido dadas a conocer las principales observaciones al respecto de pensadores clásicos como Hume, Feuerbach o Russell, o en todo caso cual si estas tuvieran poco o nada que ver para apreciar el acierto o desacierto de aquellas tesis centrales presentadas ahí por él mismo; $y$, naturalmente, sería pedirle demasiado que tenga noticia sobre los problemas de fondo abordados por Kolakowki en la materia]. Desde luego, tales omisiones en la formación intelectual de Peterson no son advertidas por quienes dialogan con él en numerosos vídeos de YouTube, tanto da si aquellos se cuentan entre sus numerosos admiradores o si son unos interpeladores de nivel intelectual tan precario como los propagandistas de la ideología de 
Para Peterson, maravillado ante «saberes» como aquellos de Žižek, estos vinieron a significar algo así, mutatis mutandis, como la célebre «prueba» algebraica de veracidad que sobre existencia de Dios se le atribuye al matemático Euler: $«(\mathrm{a}+\mathrm{bn}) / \mathrm{n}=\mathrm{x}$, por tanto Dios existe. ¿Algo que objetar?». Análogo papel de evasión discursiva lo desempeñó ahora el «álgebra» de filosofemas idealistas desgranado ahí por Žižek. Una vez atrapado en el «mosquitero» ${ }^{81}$ de esta dimensión discursiva, elucidaciones a propósito de sociedades pergeñadas a la medida de los gustos teoréticos del social dreammaking académico (falacia intelectualista ${ }^{82}$ ) conjurado allí por Žižek, no es de extrañar que Peterson haya pasado a hacer causa común con aquel mismo en, justamente, dejar de lado el discernir las cruciales cuestiones prácticas abordadas en la intervención inicial de esa actividad.

En cuanto al auditorio ulterior (ii), cabe pensar que la recepción por parte de tales espectadores puede ser menos emocionalizada, puesto que entonces se está en condiciones de analizar pausadamente las razones presentadas. Pero muy probablemente no tienen la paciencia de detenerse a ver ese evento por entero sino profesores universitarios de filosofía, gremio donde la voz cantante es de quienes se limitan a tomar en consideración sobre todo

«género»; es muy poco probable que los primeros, tampoco ellos, estén familiarizados con estudios del tipo de esos cuyo conocimiento brilla por su ausencia en enfoques de Peterson. Así es cómo, enfrentado al «esperanto» de Žižek, aquel se haya encontrado entonces con la sorpresa -inimpugnable para su propia esfera de conocimientos (iy des-conocimientos!) — de topar con dificultades que, por cierto, no tiene ante los auditorios («facilitos» intelectualmente) donde expone para YouTube. -Pues sí, Žižek «la tuvo fácil» ante alguien como Peterson. Seguramente lo adivirtió de antemano; en caso contrario, difícilmente hubiera aceptado el debate (no lo veo atreviéndose a responder ante verdaderos conocedores de las dinámicas sociocolectivas: ¡ni imaginar qué reverendo papelón hubiera hecho si al frente hubiera tenido ahí, en vez de Peterson, p. ej. a Thomas Sowell!).

Supra: n. 24. (cuando no exclusivamente) teorizaciones idealizantes como materia de reflexión. En cambio, por cuanto respecta a quienes tengan asentado el hábito de someter propiamente a análisis las «construcciones sociales de la realidad» (Berger/Luckmann), tanto en lo lingüístico (des-cubrir «fórmulas vacías» y otros expedientes retóricos en esos juegos de lenguaje) como en lo pragmático-empírico (conductas efectivas de los protagonistas sociales, prácticas políticas reales), no es probable que posean la paciencia como para seguir por mucho rato los juegos lingüísticos del pandemónium de términos vago-emocionalizantes y mosaicos de trivialidades maquilladas en grandilocuencias que despacha Žižek.

No es de extrañar, pues, que en general los comentarios sobre ese evento aparecidos en YouTube estén centrados sobre la circunstancia de que Žižek mostró tener conocimientos más amplios que Peterson sobre qué dijeron unos autores [supra $\S 7$ ], y sean bienvenidas asimismo ciertas otras distracciones especulativas introducidas por aquel. Visto el asunto así - esto es: concentrada la atención sobre unas cuestiones de erudición filosófica ${ }^{83}$, y siempre sin decir «agua viene» sobre la retórica de las fórmulas vacías usadas allí mismo-, a especialistas en filosofía profesoral no les costó mucho convencerse de que Žižek habría abordado la temática con «profundidad» ejemplar, vale decir: ¡suministrar con justamente esto, el «esperanto» en cuestión, toda una lección magistral a Peterson!

Pues sí, cabe reconocer que Žižek «ganó», acaso hasta por goleada, ante los ojos de quienes festejan que el examen de los dinamismos sociales consista en elucidar cómo funcionarían las organizaciones humanas if men were angels... ${ }^{84}$.

83 De los siete tipos de cuestiones claves [a)-g)] señalados más atrás [\$ 4.ß)], esos comentaristas no dedican verdadera atención, ni siquiera los discriminan, salvo a ciertos aspectos que pertenecen principalmente al punto c).

84 Acotación. - Eso sí, no hay por qué pensar que tales modalidades de pensamiento («idealismo especulativo») estén reservados solamente, en la actualidad, para académicos cuyas divagaciones se 
[D]

ADDENDUM

\section{MARAVILLAS SOCIALES DE ÚLTIMA HORA, AVISTADAS (PROFETIZADAS) GRACIAS A LA INTERVENCIÓN SALVÍFICA DEL COVID-19}

The products of thougt are hipostasized and actual reality despised

Vahinger (como se citó en Frank, 1970, p. 343) ${ }^{85}$

Estas anotaciones se dirigen principalmente $[a, b]$, en concordancia con la temática central del presente trabajo, a poner en evidencia asimismo la falaciosidad de la «técnica» de razonamiento desempeñada por Žižek para abordar la problemática social desencadenada por el covid-1986. Al final [c] añadiré

vuelcan a legitimar ideologías llamadas de «izquierda». Por otro lado están también celebrados wishful thinkers de teoría política «democrática»: lo más publicitado contemporáneamente para esta otra vereda son, si no estoy equivocado, el idealismo político de Rawls y el de Nozick, dos modelos de falacia intelectualista entre los cuales disputan sus preferencias profesores de Teoría Política. [Mas es justo reconocer que ni Rawls ni Nozick llegan a los extremos más incontenidamente delirantes de teorización autista para estas materias: p. ej., véase la alucinación de data más reciente llamada «Parecón» (Michael Albert)]. Sobre la impronta general del wishful thinking en las ciencias sociales, cfr. Haba, 2010b.

85 Nombre completo: Hans Vahinger (1852-1933).

86 Para un examen circunstanciado sobre este asunto, véase la contraposición de ideas entre las posiciones expuestas en los dos sitios siguientes, enfrentados entre sí: Agamben et al., 2020 vs. Lukaks, 3 de julio de 2020. Información pormenorizada acerca de la «plandemia» covid-19 ofrece Martín Jiménez, 2020. Para no quedarse en el hegemónico relato oficial al respecto, esa línea de pensamiento único dictada por el eje OMS/gobiernos nacionales (hay excepciones)/mass media, es indispensable dirigirse a medios de información aternativos. Tal información está disponible incluso en YouTube (entre infinidad de tantas cosas, allí, de todo jaez): numerosos vídeos ahí presentan intervenciones de expertos en la materia, quienes ponen sobre el tapete información crucial que en la gran mayoría de los países no asoma en el relato oficial (véase los conocimientos científicos al respecto subrayados por investigadores como, p. ej.: Chinda Brandolino, Roxana Bruno, Mariano Borini, etc.). Cfr. también infra: n. 94. una puntualización acerca de la cuestión de fondo en sí misma, el acogimiento por ese autor de la vieja idea de postular la planificación total centralizada como solución para la convivencia humana adecuada.

Hemos tenido oportunidad de apreciar a lo largo de este artículo, una y otra vez, qué «técnica» de pensamiento es esa. La conforman, como hemos visto, unas armazones de verbalismos cuyo tipo comunicacional es vertebralmente de naturaleza vago-emocionalizante. Está enhebrado con base sobre todo en combinar $a$ piacere los siguientes núcleos retóricos típicos: fórmulas vacías, falacia intelectualista, «wishful thinking» + dejar fuera del ruedo la información científica disponible sobre los elementos de conocimiento fácticos pertinentes (ausencia completa, o muy poco menos, de datos precisos, controlables empírico-metódicamente).

Pues bien, ni más ni menos que eso mismo constituye el tipo de reflexión aplicado por Žižek más recientemente para extraer conclusiones también sobre por qué, cómo y proféticamente para qué, el covid-19 vino a intervenir en nuestras vidas actuales. Se trata de algo así, estas predicciones/anhelos sobre ese futuro que avista el iluminado tándem Kill-Bill/Žižek, como cuando escuchamos a quienes están convencidos de descifrar conocimientos proféticos cruciales en las notas dejadas por Nostradamus.

Han cosechado no poca difusión dichos augurios; provienen, in nuce, de fantasías de organización política universalista pergeñadas variadamente desde siglos atrás. Ideas como esas se toman en serio todavía hasta por científicos sociales, a pesar de la contundente evidencia empírica suministrada desde el siglo pasado sobre cómo funcionan de veras las organizaciones totalitarias. Ante el hecho de semejante consideración pública (¡únicamente en atención a esta misma!), me parece que no viene enteramente de más examinar aquí aun estas otras especulaciones de dicho autor. También estos distraccionismos doctrinarios más recientes se asientan en los susodichos tipos de ingredientes discursivo-retóricos, esas consideraciones suyas a propósito del covid-19 no son menos hegeliano-galáxicas (trivialidades aparte) que su recetario en relación con la «felicidad». 
Voy a examinar unas ideas enfatizadas por Žižek en su intervención inicial sobre el susodicho asunto (Žižek, 2020) ${ }^{87}$. Para cada cita, va primero su transcripción literal, donde destacaré con cursivas unas vago-emotivaciones verbalistas típicas; a continuación desglosaré respectivamente ciertos elementos centrales de su engañosidad discursiva.

\section{[a]}

«... quizás otro virus ideológico, y mucho más beneficioso, se propagará y con suerte nos infectará: el virus de pensar en una sociedad alternativa, una sociedad más allá del estado-nación, una sociedad que se actualiza a sí misma en las formas de solidaridad y cooperación global (..) el coronavirus también nos obligará a reinventar el comunismo basado en la confianza en las personas y en la ciencia» (Žižek, 2020, p. 22).

Desde luego, no pongo en duda que quienquiera puede llegar a «pensar» en este, o en cualquier otro, collage de saludos a la bandera ${ }^{88}$. Solo que, ¿habrá quien de veras necesite bañar su mente en las aguas de estos conciertos de verbalismo («musica di

87 Žižek publicó poco después un libro sobre el asunto. Sería no poco asombroso, vistos sus antecedentes como «pensador», que ahí él haya abordado las cuestiones de manera menos galáxica; antes bien, no es improbable que tal publicación le sea propicia para añadir buen número de aun otros distraccionismos académico-celestiales al respecto. No habiéndome yo tomado por añadidura la molestia de examinar también ese otro texto, por supuesto no me es dable afirmar a ciencia cierta que ahí la mente de Žižek no haya venido a experimentar acaso una repentina transformación milagrosa. ¡Vaya Dios a saber qué portentos de perspicacia me pierdo por no enterarme de eso! Y háyase producido o no tanta maravilla, quede subrayada la advertencia siguiente: las observaciones mías aquí son acerca de las dos intervenciones específicas de ese autor consignadas en la bibliografía del presente artículo. parole» ${ }^{89}$ ), para lograr colocarse en el mood de avistar soluciones de ordenación social específicas? Vale decir: soluciones intersubjetivamente diferenciables (específicas), inferidas propiamente (por vías de pensamiento igualmente intersubjetivas) de estos términos mismos (esos pregonados por Žižek). Veamos si es o no es así.

¿Qué «solidaridad», cuáles modos de «cooperación», todo ello llevado a cabo cómo en concreto? ¿Son obvias las respuestas? ¿Basta con ofrecer el singular descubrimiento de que es dable «pensar» en estas nobles palabras, sin aclarar en cuáles órdenes específicos de relaciones sociales y entre quiénes? ¿Se trataría de todos, o casi todos, los seres humanos, en todos los momentos de sus vidas, cada quien relacionándose así con la totalidad de las demás personas del planeta?

O bien, si Žižek está dispuesto a admitir que cada una de esas relaciones de «confianza» no se llevaría a cabo con todas (o casi todas) las «personas» — por tanto, no siempre, no incondicionalmente-: entonces, ¿con qué «personas» sí y con cuáles no entraríamos en «confianza», cómo determinar intersubjetivamente quiénes son las unas y quiénes las otras? Más aún: ¿quiénes serían los sujetos encargados de reconocer que se dan ahí dichas relaciones? (suponiendo que Žižek vislumbre alguna posibilidad de que, al menos a veces, no todos los individuos habidos y por haber estén unánimemente de acuerdo). Esta pregunta no es superflua, puesto que, sea como fuere, habrá individuos concretos - sí, junos dirigentes! - encargados de dictaminar quiénes sí, y quiénes no, formen parte de tales o cuales «relaciones», reconocer y controlar cuáles son las maneras admitidas para hacerlo.

Puédalo o no «pensar» Žižek, y otros, no se echa de ver dónde y cómo puedan existir unas «relaciones» en el espacio y en el tiempo -vale decir: empíricamente dadas y empíricamente reconocibles, como tales- que estén pura y simplemente abiertas, sin más, a que

$89 \quad$ Supra: n. 46. 
en sus actividades propias y beneficios propios participe (¡hasta afuera de ciertos universos de textos!) cualquier ser humano, con solo que este manifieste su deseo de intervenir ahí. ¿Es necesario hacer recordar aun la trivialidad siguiente?: dicho sin ninguna suerte de eufemismos, es imposible que las organizaciones sociales, desde unas pequeñas (instituciones bien determinadas) hasta las más grandes (países, entes internacionales), puedan funcionar sin someterse a unos controles ejercidos por individuos-autoridades.

Pues bien, en ese mundo postcovid «pensado» por Žižek: ¿los sujetos que ahí desempeñen funciones superiores de «quiénes»autoridad serían elegidos por voto popular? -y este, en su caso, ¿organizado cómo?-. 0 bien, ¿ahí decidirán sobre todas las cuestiones principales de organización social tales o cuales burócratas internacionales? [La contestación de Žižek va muy netamente, al parecer, en la dirección de imponer como Führer una autocracia internacional: infra, punto c].

Pareciera que, por algún prodigio de transformación en la naturaleza humana, cuya fórmula de realización nos revelará oportunamente la sabiduría «dialéctica» de Žižek (o tal vez la de unos aventajados alumnos suyos), todos esos prosaicos cómo resultarán evidentes para todas y cada una de las «personas» de nuestra especie. Esto es, cabría pensar que los jerarcas internacionales contarían de por sí con el asentimiento de tales «personas», siempre o casi siempre.

En ese futuro luminoso que Žižek nos vaticina estaríamos asegurados de que el gobierno mundial queda a cargo de unos adalides no menos desinteresados que ultrasapientes (cada uno encarnando algo así como el filósofo-rey concebido por Platón). Y aun si por ventura no en absolutamente todos los casos hubiere concordancia plena de ideas entre lo decidido por estos guías internacionales $y$ cuanto prefieran algunos otros seres humanos [... pero ignoro si Žižek considera tal posibilidad], no menos estos últimos que todas las demás «personas» del orbe gozarán del beneficio de ser felizmente (¡Huxley!) constreñidos a vivir en el mejor de los mundos posible, imperium oNU mediante. [b]

«... la epidemia de coronavirus es una especie de ataque ... contra el sistema capitalista global, una señal de que ... un cambio radical es necesario. Triste hecho, necesitamos una catástrofe» (p. 23). Tal cambio, inducido por esta «catástrofe» $\tan$ auspiciosamente oportuna, consistiría en que gracias a ella se abre paso «la necesidad urgente de una reorganización de la economía global que ya no estará a merced de los mecanismos del mercado ... algún tipo de organización global que pueda controlar y regular la economía, así como limitar la soberanía de los estados nacionales» (Žižek, 2020, p. 27).

Bonito, bonito... Pero vayamos por partes:

¿Hay manera de conocer qué quiere decir ahí «global»? ¿Significa, tal vez, TODAS y cada una de las regulaciones de mercado en cada país? -i.e.: en todos estos, como también para todas las relaciones entre ellos $y$ todas las medidas de organizaciones internacionales al respecto-. ¿Será que todo eso («sistema capitalista») resulta «atacado» por el virus del mismo modo, sin más? ¿Va ello en medida igual (aproximadamente) para cada uno de quienes desempeñen algún «negocio», sea este cual fuere?

Considerando el «capitalismo» tal como funciona realmente en distintos países, ahî sometido ya desde mucho tiempo atrás a numerosísimas intervenciones estatales que restringen sensiblemente la libertad de mercado: ¿cabría mantener tal vez algunas de estas libertades (¿cuáles?), en ciertas medidas (¿cuáles?)? ¿O será cuestión, sencillamente, de eliminarlas en su totalidad de raíz y reemplazarlas por medidas de control burocrático inéditas que sean salvíficamente todo abarcantes? ¿Están llamadas a desaparecer completamente todas las posibilidades «capitalistas» actuales, o unas sí y otras no? Y en este último caso, ¿¿cuáles sí y cuáles no?

Cambio «radical»: ¿en qué han de consistir concretamente las novedades (si es admisible nombrar esto en forma laica) pregonadas así? 
¿Cuáles serían entonces en especie, respectivamente, las regulaciones interno-estatales $y$ cuáles quedarían reservadas para la facultad de fijarlas motu proprio los omniscientes burócratas internacionales? ¿O será que, al fin de cuentas, no cabrían ya las primeras si no es por delegación consentida de dicha burocracia o en espacios muy secundarios sobre los cuales a esta misma no le interese complicarse la vida en distraer su atención?

Por lo demás, ¡chica cosa!: ¿cómo se determinaría quiénes conforman esta burocracia mundialista, al menos sus cargos jerárquicos superiores? ¿Será seleccionada mediante algún sistema de cooptación (acaso como los gobernantes chinos en la actualidad) o bien esas autoridades formales serían impuestas ahí por uno o más círculos de megaagentes económi$\cos$ (como los reunidos en el Club Bilderberg ${ }^{90}$ $\mathrm{u}$ otros consorcios económicos formidables, actuales o futuros)? [Más abajo (a la altura de la n. 92) nos enteraremos de que la supremacía universal de dichos burócratas es la solución en que Žižek deposita sus esperanzas más «realistas», por ahora en asocio con la intervención oportunísima del covid-19].

Lo «necesario»: ¿esto se dice, en el pasaje transcrito, en el sentido de nombrar cierto ideal («debe»)? Por tanto, propósitos contingentes: al gusto de unos sí, de otros no. ¿O al fin de cuentas se trataría de una indefectibilidad histórica («es»), como en las teodiceas de Hegel o de Marx (leyes ineludibles del devenir social que predeterminan la Historia)?

Sea como fuere, lo cierto es que tanto en el uno como en el otro modo de entender («debe», «es»), atinar a conocer qué constituya al respecto lo supuestamente «necesario» está librado —ide hecho! — a la imaginación de cada quien o de la propaganda pública que él siga a pie juntillas. A discreción de los gustosos usuarios de esas fórmulas persuasivas queda el «pensar» qué soluciones específicas, llegado el caso, ofrecería Žižek ante tal o cual tipo de situaciones bien delimitado, supuesto que ellos puedan adivinar eso; o bien, en cambio, imputarles unos contenidos específicos muy diferentes a aquellas mismas fórmulas.

Tomar esas decisiones interpretativas es inofensivo mientras ello consista simplemente en ejercitar unas elucidaciones de orden académico (caso de Žižek o aun el mío aquí). Mas ello puede llegar a revestir efectos prácticos, como retórico apoyo comunicacional, cuando esas fórmulas las invocan operadores políticos con poderes de influencia efectivos. Entonces unas fórmulas de esa naturaleza pueden contribuir a apuntalar emocionalmente la adhesión de grupos sociales para impulsar ideológicamente tales o cuales ordenamientos de lo colectivo, disposiciones sociales que esos operadores legitiman ahí mediante estas etiquetas multimanipulables. Ordenamientos que puestos en práctica son, jestos sí!, no poco concretos en sus diferenciales efectos de hecho, ya sea favorables o desfavorables, sobre las vidas de mucha gente. Y es cierto que, a pesar de todo, alguna cosa en el planteamiento de Žižek es dable sacar en limpio sobre ello mismo, grosso modo. Lo examino a continuación.

\section{[c]}

Desde luego, no se supone que Žižek debía detallar ahí un mapa pormenorizado de cuáles podrían ser cada una de las nuevas regulaciones en que confía él. Pero no habría estado de más (digo yo) señalar al menos unas pocas pautas intersubjetivas al respecto, proporcionar cierta determinación unívoca para alguna que otra de sus divisas de belletrística política. $\mathrm{Ni}$ aun Marx y Engels lo lograron mucho para sus indicaciones programáticas; de ahí las grandes controversias teóricas al respecto entre variados autores que se autodefinen «marxistas», $y$ ni qué decir por cuanto respecta a venerar o criticar las medidas de organizaciones estatales cuyos gobernantes se proclaman seguidores de esa orientación u orientaciones. Mas es justo reconocer que, así y todo, algunas de aquellas indicaciones del marxismo original son muchísimo menos vagas ${ }^{91}$ que casi todos estos banderines enarbolados por Žižek.

91 Como medida ejemplar dirigida a frenar de antemano las ambiciones personales de las autoridades estatales en la nueva organización social, Engels 
Mas hay un señalamiento que, este sí, es no poco palpable sobre cómo concibe él «las formas de solidaridad y cooperación global» ${ }^{92}$. Helo aquí:

«El primer modelo vago de una coordinación global de este tipo es la Organización Mundial de la Salud, de la cual no obtenemos el galimatías burocrático habitual sino advertencias precisas proclamadas sin pánico. Dichas organizaciones deberían tener más poder ejecutivo» (Žižek, 2020, p. 25).

Por fin, pues, un indicio no del todo etéreo sobre cuál es el resultado práctico apetecido por nuestro autor. Si bien la idea básica al respecto no tiene nada de nuevo en sí misma, confiar en la planificación totalizadora («global») para una colectividad humana enorme, ahora nos encontramos con la indicación bien concreta de dónde está esa instancia de autoridad irresistible encargada de someter el globo terráqueo entero a sus dictados soberanos. Ingeniería social planetaria, iburocracia de la onU mediante!

Quiere decir que en definitiva, y por cierto tanto da si ello venga o no venga suplido con un multipalabrerío adyacente, lo que a este académico le ilusiona ${ }^{93}$ sobre toda otra cosa es

indicó expresamente: «Contra esta transformación del Estado y de los órganos del Estado de servidores de la sociedad en señores de ella ... todos los funcionarios, altos y bajos, estaban [en la Comuna de París, 1871] retribuidos como los demás trabajadores. (...) Con este sistema se ponía una barrera eficaz al arribismo y a la caza de cargos» [Intr. de Engels a: Marx, La guerra civil en Francia (en Marx y Engels, 1951, p. 450, curs. añadidas aquí)]. —¿Es por casualidad que Žižek, no menos que Dussel, Do Santos y tutti quanti ideólogos de la «liberación», no consideran que vale la pena volcar la mirada hacia detallillos como esos? (... pequeños olvidos por parte de los Castro, Chávez, Morales, Ortega, Lula, Kirchner, suma y sigue).

92 Tales palabras se encuentran en la transcripción ubicada supra, punto [a] in limine.

93 Desde luego, ponen sus mejores esperanzas en ello no solamente él y un puñado de «pensadores» afines (Aganbem et al., 2020). Responde asimismo, desde bastante antes, a esfuerzos (manifestados públicamente) de grandes filántropos como los que se consiga imponer en la mayor medida posible lo siguiente: asegurar que las conductas de los seres humanos vengan sometidas desde «arriba» por una instancia mundial suprema, con poderes irrefrenables, ejercidos sobre los ciudadanos de todos los países indistintamente. Dado que esta vez esa centralización que él nos augura conseguiría ser la más extensamente totalitaria habida y por haber, ni más ni menos, justamente eso garantizará sus maravillosas bondades inéditas.

[Vaya a saber, pero es harina de otro costal, qué eficientísimo conjuro de maldiciones manejadas por el colectivo de nigromantes especializados en brindar sus buenos oficios al capitalismo ha conseguido, una y otra vez, que los dirigentes de los Estados totalitarios históricamente dados no pudieron hacer práctico que la población de sus respectivos países contara con esos resultados prodigiosos; ni aun por más que dichos dirigentes contaron hasta con el surplus de ciencia social máximamente lúcida de que los hacía beneficiarios sus conocimientos incuestionables de materialismo histórico. Empero, si bien las nomenklaturas de los Estados autoproclamados marxistas-leninistas no han llegado cada una a ejercer de manera adecuada (sea por lo que fuere) sus funciones totalitarias nacionales, no habría por qué dejar de confiar - según Žižek - en que la neo-nomenklatura mundialista, iella sí!, hará llover sobre la gente las bendiciones de un depurado totalitarismo mundial ajeno a «pecadillos» semejantes].

Para saber a qué atenernos, he aquí la fascinación de Žižek ante lo que es la oms... ¡nada menos! Queda bien en claro, pues, el modelo en qué inspirarse para guiar a la luminosa «sociedad alternativa» ${ }^{94}$ que nos augura él. —Difícilmente podría haberse ofrecido ejemplo más revelador. Aun haciendo abstracción de los no poco hondos cuestionamientos revelados con respecto a tantas otras actuaciones de ese ente $y$ sobre su actual Director General ${ }^{95}$,

Rockefeller, Gates, Soros y otros megamagnates, de espíritu no menos universalista todos ellos. Referencia: ídem

95 Abundantísima información sobre ello en Internet, así los sitios siguientes: Medina, 2 de junio de 
si algo hay que está más allá de toda duda es la singular ineficiencia ${ }^{96}$ que ese costosísimo cuerpo burocrático ha puesto de manifiesto en cuanto, ijustamente!, al asunto del coronavirus.

$$
* * *
$$

Los individuos (nomenklatura: la «nueva clase» señalada por Djilas) que mandan, a la vez que acaparan los privilegios de máximos beneficios sociales, en los totalitarismos plenos no alcanzan a imponer sus ukases más allá del

2020; El Confidencial, 2020; Carrillo, 25 de abril de 2020; Amos del Mundo, 20 de abril de 2020; y muchos más detalles ofrece Martín Jiménez, 2020. Desde luego, no es imposible que hechos señalados en esas fuentes no sean verídicos (en todo o en parte); sin embargo, no he conseguido descubrir sitios acreditados donde la existencia de dichos hechos como TALEs - iestos en sí mismos! - se niegue de modo puntual respectivamente (en todo o en parte) —esto es, más allá de que se acepte o no unas inferencias que el propio expositor extraiga a partir de aquellos-. No deja de llamar la atención asimismo que YouTube ejerce, iconfesamente!, censura sobre las posibilidades de cuestionar abiertamente la palabra oficial de la oms [p. ej., véase: https://www.youtube. com/watch?v=oOkCSpsJjHQ\&t=633s]; Google no se queda atrás [cfr. https://www.youtube.com/ watch? $v=$ txI-ipC9nlc $(18 / 07 / 20)]$. También, por cierto, no es dable encontrar información de esa índole en los mass media; y ni qué hablar de que estos se abran a la posibilidad de exámenes abiertos sobre ello, vale decir, aceptar que ahí participen incluso conocedores del tema que den a conocer posiciones «políticamente incorrectas». - Sin embargo, no hay por qué pensar que por acaso Žižek tenga noticia sobre algo de ello (... poco sería de extrañar que no le sea conocido el nombre de dicho Secretario General). Y menos que menos, ¡faltaba más!, es cuestión de echarle en cara que en los cumulus nimbus del Espíritu Absoluto que se complace en susurrarle a él sus saberes futuristas, ahí donde habitan «las formas de solidaridad y cooperación global» por venir, no haya lugar para enterarse de nimiedades, fijarse en cuestiones nada transcendentales como examinar si son o no son verídicas esas informaciones que señalan los sitios que he indicado.

96 Digo «ineficiencia», simplemente eso, calificativo que permite no considerar respuesta alguna, aquí, sobre si ello tiene o no tiene que ver con bases de fondo como cuanto se examina en los sitios indicados supra: n. 94. propio espacio territorial interno, respectivamente, de tales o cuales Estados en particular (URSS, China, «democracias populares» europeas, Cuba, Vietnam, Corea del Norte). La esperanza de Žižek, en cambio, se deposita en un Leviatán burocrático mucho más imponente: su órbita ha de ser mundial. Supertotalitarismo «global», pleno imperium urbi et orbi de los órdenes pronunciadas por las cópulas de la $\mathrm{ONU}$, lo comandado por sus funcionarios se extendería sobre la especie humana sin excepciones [Va de suyo que ellos no serán electos mediante votación directa por los ciudadanos de cada país-provincia tutelado así. ¿Para qué arriesgar que tal vez unos gobernantes nacionales, ignorantemente colocados ahí por sus compatriotas mismos, dispongan de poderes como para llegar a desviarse acaso de la buena senda?].

Es obvio, para Žižek, que unos burócratas internacionales, ya sea en virtud de su propia naturaleza personal excepcionalísima o mediante alguna ósmosis de santidad suministrada por lo internacionalista que es el oxígeno en sus oficinas, ellos están provistos, a diferencia (será obligatorio reconocerlo) del resto de los mortales, de todos los atributos personales $y$ condiciones materiales que hagan falta para encargarse eficazmente de organizar la redención del género humano. Al ocupar esos cargos, estas personas harán efectiva su vocación incondicional de desinteresado servicio al prójimo en general, $y$ desde luego lo llevarán adelante a las mil maravillas. ¿Qué duda puede caber?

En la visión original del marxismo, el «agente histórico» de la Misión para conquistar un «estadio superior» de la humanidad eran los desesperados proletarios, quienes ya no tendrían otra opción que romper, a punta de heroicidad revolucionaria, las brutales «cadenas» económicas que los sumergían en la miseria cada vez mayor y mayor. No les quedaba más por perder, decía Marx, que esas «cadenas» mismas.

A la luz del «marxismo» modus Žižek, afortunadamente la cosa no tiene por qué ser sanguinolenta, sino cuestión de que la humanidad confíe en los comandos burocráticos internacionales. El cambio de los tiempos hace que, por dicha, los herederos actuales del Gran 
Encargo pasen a cumplir con Él en habitáculos un poco menos insalubres que los cuchitriles de aquellos proletarios, ahora son unos modestos edificios asignados para oficinas de las Naciones Unidas.

Y gracias a cuán oportunamente nos viene la «catástrofe» ${ }^{97}$ desencadenada por nuestro virus esperanzador, para disfrutar de los tiempos gozosos por venir no hará falta que estos se inauguren mediante levantamientos en armas inducidos por un nuevo Lenin. Bastará sentarse a disfrutar de cómo seremos manejados por los funcionarios que estén bajo el mando de unos muy bienvenidos Tedros Adhanom Ghebreyesus.

\section{REFERENCIAS}

Agamben, G., ŽiŽek, S., Nancy, J. L., Berardi, F., López, S., Butler, J., Badiou, A., Harvey, D., Han, B., Zibechi, R., Galindo, M. Gabriel, M., Yañez, G., Manrique, P. y Preciado, P. (2020). Sopa de Wuhan: Pensamiento contemporáneo en tiempos de pandemia. Editorial ASPO (Aislamiento Social Preventivo y Obligatorio). http:// otrasvoceseneducacion.org/wp-content/ uploads/2020/04/Sopa-de-Wuhan-ASPO.pdf

Albert, H. (1973). Tratado sobre la razón crítica (trad. R. Gutiérrez Girardot). Sur.

Amos del Mundo (20 de abril de 2020). La verdad sobre la oms y sus 2 jefes secretos. [Archivo de Vídeo]. YouTube. https://www.youtube.com/ watch? $v=$ WpcutGIUcMY

Berger, P. y Luckmann, T. (1968). La construcción social de la realidad (trad. S. Zuleta, rev. técn. M. Giménez Zapiola). Amorrortu.

Bourdieu, P., Chamboredon, J. C. y Passeron, J.C. (Eds.) (1985). El oficio del Sociólogo. Siglo XXI.

Bouveresse, J. (2001). Privilegios y vértigos de la analogía (Pról. A. Sokal y J. Bricmont). Libros del Zorzal.

Carrillo, R. (25 de abril de 2020). La verdad sobre la oms. [Archivo de Vídeo].

97 Supra: punto [b] in limine.
YouTube. https://www.youtube.com/ watch? $v=$ DcmGo4krK5A\&t=89s

Castilla del Pino, C. (1974). Introducción a la hermenéutica del lenguaje. Península.

Cioran, E. M. (2006). Ébauches de vertige. Gallimard.

Debray, R. (1983). Crítica de la razón política (trad. Pilar Calvo). Cátedra.

Degenkolbe, G. (1965). Über logische Struktur und Gesellschaftliche Funktionen von Leerformeln. Kölner Zeitschrift für Soziologie und Sozialpsyphologie, 17, 327-338.

El Confidencial (2020). ¿Qué pasa entre oms y China? Una relación que levanta sospechas. [Archivo de Vídeo]. YouTube. https://www.youtube.com/watch? $v=\_d 7 j-$ dvaNXY

Fetscher, I. (1971). Carlos Marx y el marxismo. Monte Ávila.

Frank, J. (1942). If Men were Angels. Harper \& Brothers.

Frank, J. (1970). Law and the Modern Mind. Peter Smith.

Gouldner, A. W. (1983). Los dos marxismos: Contradicciones y anomalías en el desarrollo de la teoría (trad. N. A. Míguez). Alianza Editorial.

Haba, E. P. (1976). La idea de Totalitarismo y la libertad individual. Autopsia de una noción mistificadora. Temis.

Haba, E. P. (1986). Tratado básico de derechos humanos, tomos I (Conceptos Fundamentales) y II (Indicadores Constitucionales). Juricentro. [Una versión revisada se publicará próximamente en B. Molina Editores].

Haba, E. P. (enero-junio, 1992). Retórica de "la" Libertad contra las libertades (Control sobre las libertades, por medio de "la" Libertad como ideología). Revista de la Facultad de Derecho, 2, 129-168 (Universidad de la República, Uruguay). [Publ. también, con leves correcciones, en Revista de Ciencias Jurídicas (UCR), 75 (mayo-agosto 1993), 113-158; es la versión definitiva (revisada y ampliada) del texto publicado antes en varios otros sitios, donde llevaba como título lo 
que ahora pasó a ser el subtítulo entre paréntesis].

Haba, E. P (setiembre-diciembre, 1996). Estrategias del wishfull thinking en una moderna Santa Familia: sobre Habermas, Rawls. etc. De la concepción "misionera" en las ciencias sociales. Revista de Ciencias Sociales (UCR), 73-74, 145-157. [Los desarrollos presentados en ese estudio pasaron a formar parte de Haba, 2010b: esp. cap. v].

Haba, E. P. (2006). Metodología jurídica irreverente. Elementos de profilaxis para encarar los discursos jurídicos terrenales. Dykinson. [La totalidad de lo contenido en esa obra pasó a formar parte, junto con mucho otro material, de la versión muy ampliamente reelaborada: Haba, 2012].

Haba, E. P. (2007). Contra la «Santa (charla-) Familia». Anclajes básicos de la vocación astronáutica promovida por Rawls, Habermas y otros apóstoles del wishful thinking académico. Doxa, 30, 491-524.

Haba, E. P. (2009). Rawls: El extraterrestre raciocinante. Teoría social en tanto que mero divertimento discursivo (Sobre la neoescolástica social de J. Rawls como paradigma de teorización alienada). Revista Telemática de Filosofía del Derecho, 12, 233-267. [Recogido en Haba, 2010b: cap. v].

Haba, E. P. (2010a). Los juicios de valor. Elementos básicos de Axiología General. Editorial ucR ( $2^{\mathrm{a}}$ ed., corr. $y$ ampl.).

Haba, E. P. (2010b). Entre tecnócratas y wishful thinkers. La visión misionera de las ciencias sociales. Comares. [Parte de los contenidos de este libro fueron adelantados en una serie de cinco artículos sobre «la concepción "misionera"» publicados por el autor en Revista de Ciencias Sociales (UCR); Nros. 64 (junio 1994, 109-119), 70 (dic. 1995, 69-81), 71 (marzo 1996, 73-86), 72 (junio 1996, 171-186), 73-74 (set-dic. 1996, 145-157)].

Haba, E. P. (2012). Metodología (realista) del Derecho. Claves para el razonamiento jurídico de visión social práctica. Editorial UCR, Tomos I y II (impresos),
Tomo III (CD). [Una nueva edición (revisada y con ampliaciones) está programada para publicar en 2021].

Haba, E. P. (2013). La opción capital para los razonamientos jurídicos: ¿novelas de conceptos o una tecnología social?, 36, 509-550. [Una versión revisada (reorganizada, también con algunos pasajes suprimidos y otros añadidos), se publicó en Empório do Direito, 12/11/2015].

Haba, E. P. (2015). ¿Qué es «realidad» jurídica? De cómo aprehenderla en cuanto a los discursos jurídicos. Revista Telemática de Filosofía del Derecho, 18, 67-130.

Haba, E. P. (2016). Axiología Jurídica Fundamental. Bases de valoración en el discurso jurídico. Editorial UCR $\left(3^{\mathrm{a}}\right.$ ed., versión revisada y ampliada).

Haba, E. P. (2019). ¿Por qué, y cómo, son «inconmensurables» las teorías jurídicas? Sobre modos de «hablar» con que las doctrinas hegemónicas en la Teoría del Derecho se las ingenian para no afrontar el principio de realidad. Revista Telemática de Filosofía del Derecho, 22, 17-78.

Haba, E. P. (3 de mayo de 2019). Anotaciones para no acoplarse al efecto-Vicente (ni sucumbir ante el cerco del «correctismo» profesoral). Empório do Direito. https://emporiododireito.com.br/leitura/ anotaciones-para-no-acoplarse-al-efectovicente-ni-sucumbir-ante-el-cerco-delcorrectismo-profesoral.

Hospers, J. (1964). La conducta humana (trad. J. Cerón). Tecnos.

Kaiser, A. (5 de junio de 2017). Inmigración. [Archivo de Vídeo]. YouTube. h t t p s://www.youtube.com/ watch?v=01gcAHm7a4I

Kaiser, A. (6 de noviembre de 2018). El progreso de la infelicidad. [Archivo de Vídeo]. YouTube. https://www.youtube.com/ watch? $v=\mathrm{nZ} 4 \mathrm{bVHnOmPM \& t}=44 \mathrm{~s}$

Kaiser, A. y Brennan, J. (26 de julio de 2019). Entrevista: Capitalismo vs. Socialismo. [Archivo de Vídeo]. YouTube. https:// www.youtube.com/watch? $v=2$ M6oskZxXU\&t=644s 
Kaiser, A. (2020). La neoinquisición. Persecusión, censura y decadencia cultural en el siglo XXI. Deusto.

Kelsen, H. (1966). Justicia y Derecho Natural (trad. E. Díaz). En Kelsen, Bobbio y otros, Crítica del Derecho Natural (pp. 29-163). Taurus.

Koch, H.J. (Ed.) (1977). Seminar. die juristische Methode im Staatsrecht. Über Grenzen von Verfassungs- und Geserzezbindung. Suhrkamp.

Kolakowski, L. (1975). La presencia del mito (trad. C. Piechocki). Amorrortu.

Kolakowsk, L. (1980). Las principales corrientes del marxismo (trad. J. Vigil). Tres vols. Alianza Editorial.

Kriele, M. (1963). Kriterien der Gerechtigkeit. Duncker \& Humblot.

Lukacs, M. (3 de julio de 2020). Pandemonium. Universidad de San Martín de Porres/ Beltramo, Villamor, Cortés. Laje, Lukacs. [Archivo de Vídeo]. Youtube. https://www. youtube.com/watch? $v=0$ gir8seCq8M

Macdonald, M. (1951). The Language of Political Theory. En A. G. Flew (Ed.), Essays on Logic and Language (First Series) (pp. 167-186). Basic Blackwell.

Martín Jiménez, C. (2013). Perdidos. Los planes secretos del Club Bilderberg, Madrid: Martínez Roca. [Comentario breve, reciente, 25 de febrero de 2020: Cristina Martín Jiménez desvela todo sobre el Club Bilderberg. [Archivo de Vídeo]. YouTube. https://www.youtube.com/ watch? $v=$ mhzeeotqCzc

Martín Jiménez, C. (2020). La verdad de la pandemia, Madrid: Martínez Roca. Visión breve, 17 de julio de 2020: El Quilombo. Entrevista a Cristina Martín Jiménez. [Archivo de Vídeo]. YouTube. https://www.youtube.com/ watch?v=MXZ51R5xlNg

Marx, C. y Engels, F. (1951). Obras escogidas en dos tomos. Tomo I. Ediciones en Lenguas Extranjeras.

Marx, C. y Engels, F. (1967). La Sagrada Familia y otros escritos filosóficos de la primera época (trad. W. Roces). Grijalbo.
Medina, A. (2 de junio de 2020). ONU, OMS y Nuevo Orden Mundial. [Archivo de Vídeo]. YouTube. https://www.youtube. com/watch? $v=g X n Q L I 5 s q Q M$

Pareto, W. (1978). Compendio di sociologia generale, Torino: Enaudi.

Perelman, C. (1964). De la justicia (trad. R. Guerra). Universidad Autónoma Nacional de México.

Peterson, J. (15 de junio de 2018). Aborto. [Archivo de Vídeo]. YouTube. h t t p s://www.youtube.com/ watch? $v=y$ WLoUYADat 0

Peterson, J. y Žižek, S. (19 de abril de 2019). Felicidad: Marxismo vs. Capitalism. [Archivo de Vídeo]. YouTube. https://www. youtube.com/watch? $v=$ Vhh-4H6pzqY

Platón (1963). República (trad. A. Camarero, Estudio preliminar y notas de L. Farré). Eudeba.

Robinson, R. (1972). Definition. Clarendon.

Russell, B. (1971). The Conquest of Happiness. Liveright. [La ed. or. es de 1930; hay publ. en cast.].

Schopenhauer, A. (2005). El arte de tener razón, expuesto en 38 estratagemas (trad. y coment. D. Garzón). Edaf.

Sorokin, P. (1964). Achaques y manías de la sociología moderna y ciencias afines (trad. L. Rodríguez Aranda). Aguilar.

Spinoza, B. (1985). Tratado teológico-politico (Selección). Tratado político (trad. y Estudio preliminar: E. Tierno Galván). Tecnos.

Stevenson, C. L. (1971). Ética y lenguaje (trad. E. A. Rabosi). Paidós.

Studebaker, B. (22 de abril de 2019). How Zizek shoud have replied to Jordan Peterson. A missed opportunity to respond to facile critiques of socialism... Ensalada Filosófica. Crítica y opinión sobre diversos tema comunes. http://ensaladafilosofica.blogspot.com/2019/04/how-zizekshould-have-replied-to-jordan.html

Topitsch, E. (1960) «Über Leerformeln. Zur Pragmatik des Sprachgebrauches in Philosophie und politischer Theorie». En Topitsch, E. (Ed.), Probleme der 
Wissenschaftstheorie (pp. 233-264). Springer.

Topitsch, E. (1966). Sozialphilosophie zwischen Ideologie und Wissenschaft ( $2^{\mathrm{a}}$ ed.), Luchterhand.

Topitsch, E. (Ed.) (1972a). Logik der Sozialwissenschaften. Kipenheuer \& Witsch.

Topitsch, E. (1972b). Sprachlogische Probleme der sozialwissenschaftlichen Theoriebildung. En Topitsch, 1972a, pp. 17-36.

Topitsch, E. (1988). Id., Erkenntnis und Illusion. J.C.B. Mohr (Paul Siebeck) (2a ed.).

Vaz Ferreira, C. (1963). Lógica viva. Homenaje de la Cámara de Representantes de la República Oriental del Uruguay, vol. IV.

Voltaire (2019). Las 100 mejores frases de Voltaire. https://www.lifeder.com/frasesde-voltaire/

Waismann, F. (1951). Verfiability. En Flew, A. G. (Ed.), Essays on Logic and Lenguage, First Series (pp. 117-144). Basil Blackwell.
Wallas, G. (1962). Human Nature in Politics (Intr. A. L. Rowse). University of Nebraska.

Weldon, W. T. (1953). The Vocabulary of Politics. Pengin Books.

Wittgenstein, L. (1953): Philosophische Untersuchungen/Philosophical Investigations. Basil Blackwell (hay trads. al español).

Žižek, S. (2020). El coronavirus es un golpe al capitalismo a lo Kill Bill y podría conducir a la reinvención del comunismo. En Agamben et al., Sopa de Wuhan: Pensamiento contemporáneo en tiempos de pandemia (pp. 21-28).

Fecha de ingreso: 08/10/2019 Fecha de aprobación: 08/10/2020 
